Linköping University Medical Dissertation No. 1620

\title{
Site and Mechanism of Action of Resin Acids on Voltage-Gated Ion Channels
}

\author{
Malin Silverå Ejneby
}

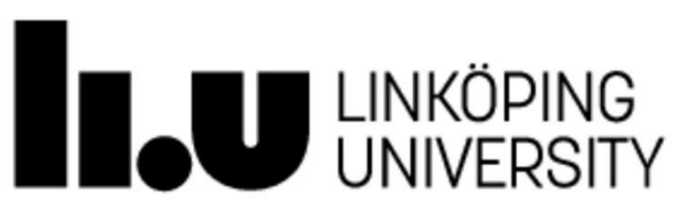

Department of Clinical and Experimental Medicine Linköping University, Sweden

Linköping 2018 
(C) Malin Silverå Ejneby, 2018

Cover illustration: "The Charged Pine Tree Anchored to the Ground" was designed and painted by Daniel Silverå Ejneby.

Printed in Sweden by LiU-Tryck, Linköping, Sweden, 2018

ISSN: 0345-0082

ISBN: 978-91-7685-318-4 


\section{TABLE OF CONTENTS}

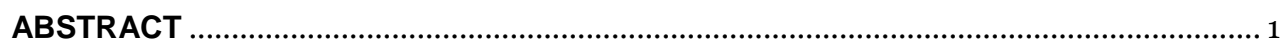

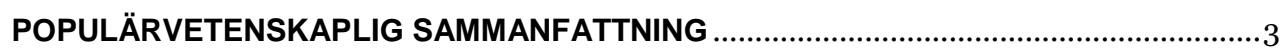

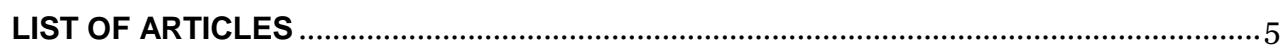

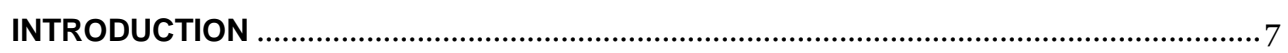

Ions underlie the electrical activity in the heart and brain ............................................. 7

A mathematical model for the nerve impulse - Hodgkin and Huxley............................. 7

Cardiac action potentials - a great diversity of shapes .............................................. 9

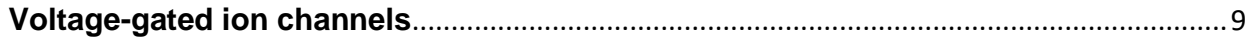

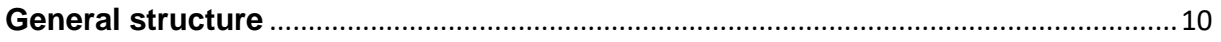

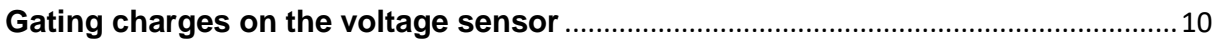

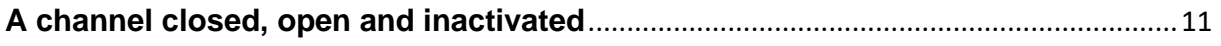

Voltage-gated ion channels as pharmacological targets ............................................ 13

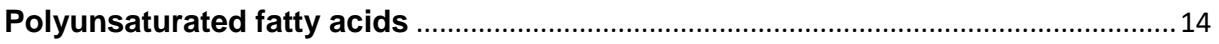

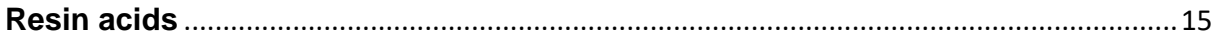

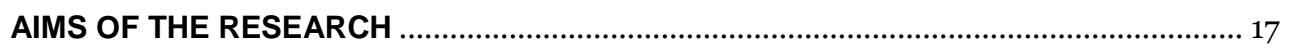

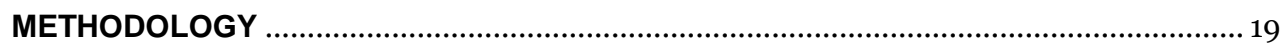

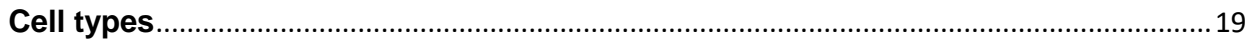

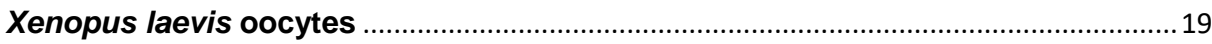

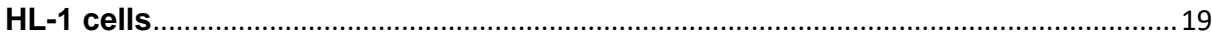

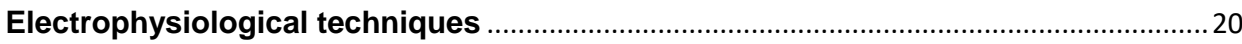

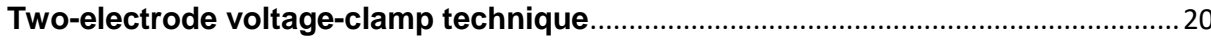

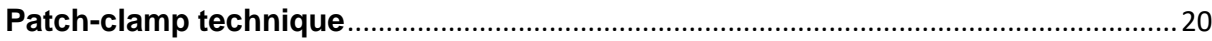

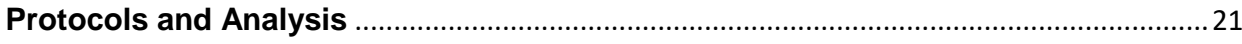

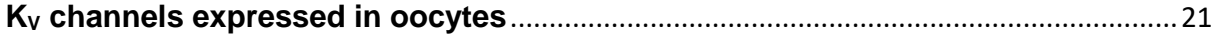

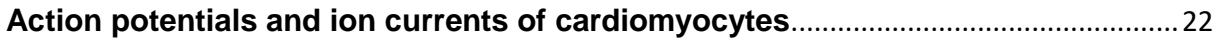

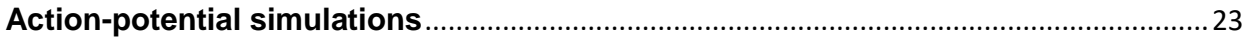

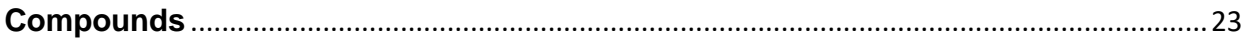

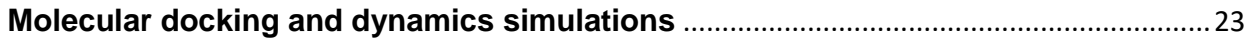

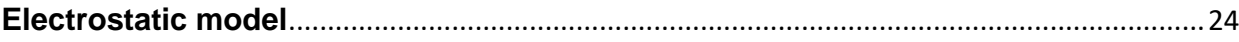

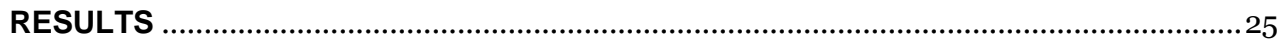

Resin acids bind to the Shaker $K_{v}$ channel in the S3/S4 cleft (Aim 1) ..........................25

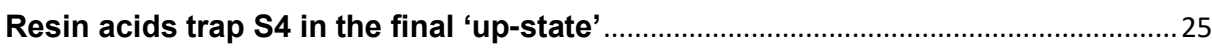

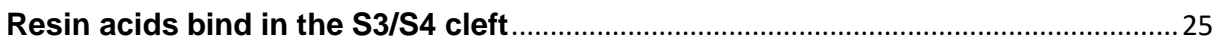

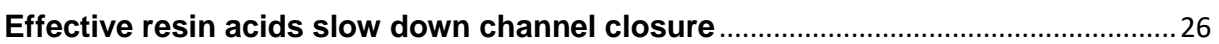


Molecular-dynamics simulations

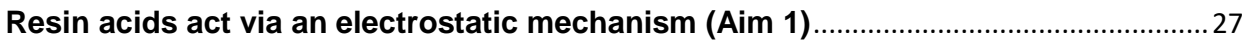

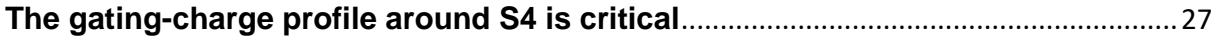

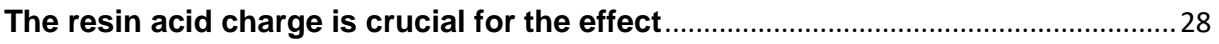

Combining modifications of the DHAA molecule increase the effect (Aim 2) .............28

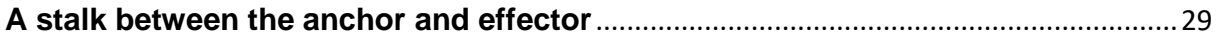

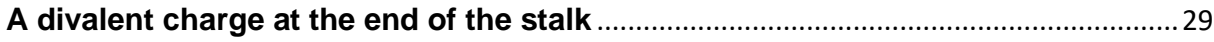

Combination of an effective anchor, stalk and effector group ..................................30

DHAA derivatives open the human M-type Kv 7.2/7.3 channel (Aim 3) .........................31

A resin acid affects cardiac excitability and several ion currents (Aim 4) .................. 31

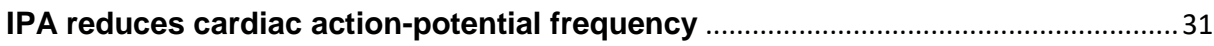

IPA shifts the gating parameters of most ion currents............................................. 32

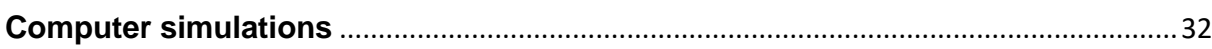

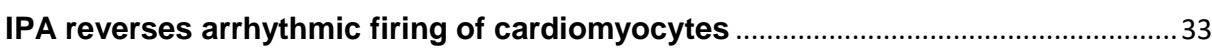

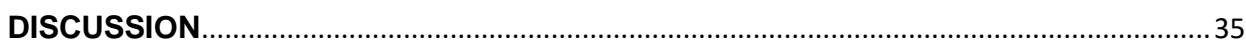

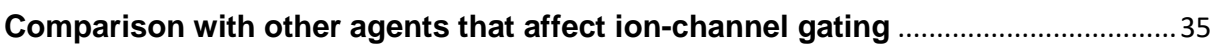

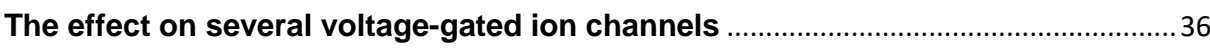

Combining modifications of a resin acid - a powerful possibility................................. 37

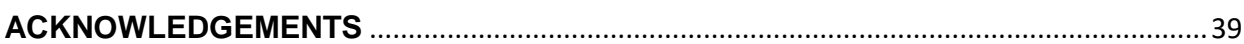

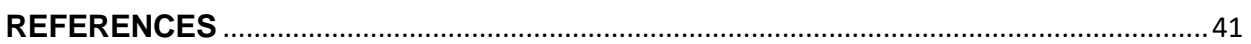




\section{ABSTRACT}

Voltage-gated ion channels are pore-forming membrane proteins that open or close their gates when the voltage across the membrane is changed. They underlie the electrical activity that enables the heart to pump blood and the brain to receive and send signals. Changes in expression, distribution, and functional properties of voltagegated ion channels can lead to diseases, such as epilepsy, cardiac arrhythmia, and pain-related disorders. Drugs that modulate the function of voltage-gated ion channels control these diseases in some patients, but the existing drugs do not adequately help all patients, and some also have severe side effects.

Resin acids are common components of pine resins, with a hydrophobic three-ringed motif and a negatively charged carboxyl group. They open big-conductance $\mathrm{Ca}^{2+-}$ activated $\mathrm{K}^{+}(\mathrm{BK})$ channels and voltage-gated potassium $\left(\mathrm{K}_{v}\right)$ channels. We aimed to characterize the binding site and mechanism of action of resin acids on a $\mathrm{Kv}$ channel and explore the effect of a resin acid by modifying the position and valence of charge of the carboxyl group. We tested the effect on several voltage-gated ion channels, including two $\mathrm{Kv}$ channels expressed in Xenopus laevis oocytes and several voltagegated ion channels expressed in cardiomyocytes. For this endeavour different electrophysiological techniques, ion channels, and cell types were used together with chemical synthesis of about 140 resin-acid derivatives, mathematical models, and computer simulations.

We found that resin acids bind between the lipid bilayer and the Shaker Kv channel, in the cleft between transmembrane segment $S_{3}$ and $S_{4}$, on the extracellular side of the voltage-sensor domain. This is a fundamentally new interaction site for smallmolecule compounds that otherwise usually bind to ion channels in pockets surrounded by water. We also showed that the resin acids open the Shaker $\mathrm{Kv}_{\mathrm{v}}$ channel via an electrostatic mechanism, exerted on the positively charged voltage sensor S4. The effect of a resin acid increased when the negatively charged carboxyl group (the effector) and the hydrophobic three-ringed motif (anchor in lipid bilayer) were separated by three atoms: longer stalks decreased the effect. The length rule, in combination with modifications of the anchor, was used to design new resin-acid derivatives that open the human M-type (Kv7.2/7.3) channel. A naturally occurring resin acid also reduced the excitability of cardiomyocytes by affecting the voltagedependence of several voltage-gated ion channels. The major finding was that the resin acid inactivated sodium and calcium channels, while it activated $\mathrm{Kv}$ channels at more negative membrane voltages. Computer simulations confirmed that the combined effect on different ion channels reduced the excitability of a cardiomyocyte. Finally, the resin acid reversed induced arrhythmic firing of the cardiomyocytes.

In conclusion, resin acids are potential drug candidates for diseases such as epilepsy and cardiac arrhythmia: knowing the binding site and mechanism of action can help to fine tune the resin acid to increase the effect, as well as the selectivity. 


\section{POPULÄRVETENSKAPLIG SAMMANFATTNING}

För att hjärnan ska fungera och hjärtat ska kunna slå är det livsviktigt att laddade joner kan förflyttas genom cellmembranet i nervceller och hjärtmuskelceller. Det ger upphov till elektiska signaler som kan sprida sig från cell till cell så att cellerna kan kommunicera. För att joner ska kunna förflyttas genom cellmembranet behöver vi olika spänningsberoende jonkanaler. Dessa kanaler formar en por genom membranet som selektivt släpper igenom en viss typ joner, så som natriumjoner eller kaliumjoner. Hur mycket joner som släpps igenom, och därmed genereringen av de elektriska signalerna, beror på om kanalens por är öppen eller stängd. För de flesta av oss fungerar dessa kanaler som de ska livet ut men ibland händer det att något går fel, kanaler kanske inte stänger när de ska, andra kanske är alldeles för mycket öppna, eller så antalet kanaler i membranet fel. Detta kan ge upphov till olika sjukdomar som epilepsi, oregelbunden hjärtrytm eller smärta. Idag finns det läkemedel mot dessa sjukdomar som hjälper vissa patienter, men långt ifrån alla, och många av dessa läkemedel har också allvarliga biverkningar.

Jag har studerat hur hartssyror, molekyler som vanligtvis finns i kåda, kan användas för att reglera öppning och stängning av spänningsberoende jonkanaler. För att göra detta användes ett flertal olika metoder, bland annat två olika elektrofysiologiska metoder som mäter elektriska spänningar och strömmar, då olika joner (laddningar) åker in i eller ut ur cellen. Vi har också syntetiserat och testat över 140 olika hartssyraderivat och använt matematiska modeller och simuleringar för att kartlägga deras effekt.

Först kartlade vi hur hartssyror interagerar med en spänningsberoende kaliumkanal (Artikel I). Vi visade att hartssyrorna binder i en ficka mellan cellmembranet och kanalen, mot utsidan av cellen, bredvid spänningssensorn, det vill säga den delen av kanalen som känner av om kanalen ska vara öppen eller stängd. Specifikt kunde vi visa att hartssyramolekylens negativa laddning hjälper till att dra upp den positivt laddade spänningssensorn till utsidan cellmembranet, genom elektrostatiska interaktioner, vilket gör det lättare för poren att öppnas. För att karakterisera och eventuellt öka den elektrostatiska interaktionen mellan hartssyran och spänningssensorn (Artikel II) förlängde vi avståndet mellan den delen av hartssyran som ankrar molekylen i cellmembranet och den negativa laddningen (effektorn). Detta ökade effekten som mest när avståndet var tre atomer. Om det kombinerades med modifikationer av ankaret och effektorn kunde vi öka effekten av hartssyran ytterligare.

Våra modifierade hartssyror öppnade en spänningsberoende kaliumkanal, den så kallade M-kanalen, redan vid en låg koncentration (Artikel II). M-kanalen är mycket viktig och när den öppnas så dämpas de elektriska signalerna i hjärnan. Av den anledningen har M-kanalen tidigare använts som mål för ett läkemedel mot epilepsi, men på grund av oönskade biverkningar används inte detta läkemedel längre. 
Vi utvärderade också effekterna av en naturligt förekommande hartssyra på hjärtmuskelceller. Hartssyran dämpade fyrningen av de elektiska signalerna i hjärtmuskelcellerna redan vid låga koncentrationer och hartssyran hade en effekt på fem av sex spänningsberoende jonkanaler (Artikel III). Intressant nog så gjorde hartssyran det lättare för poren av natriumkanaler, samt kalciumkanaler, att stängas. Dessa spänningsberoende jonkanaler ökar annars fyrningen av elektriska signaler när de öppnas. För kaliumkanaler gjorde hartssyran det lättare för poren att öppnas, som vi sett tidigare, och när kaliumkanaler öppnar minskar den elektriska aktiviteten. Således orsakar var och en av dessa effekter en minskad elektrisk aktivitet och detta kunde också styrkas med en matematisk modell. Sist men inte minst, om vi inducerade en oregelbunden elektrisk aktivitet hos hjärtmuskelcellerna så kunde hartssyran återställa det.

Sammanfattningsvis är hartssyror potentiella läkemedelskandidater för sjukdomar så som epilepsi och oregelbunden hjärtrytm. Vår kunskap om hartssyrornas bindningsställe till en spänningsberoende kaliumkanal samt resultatet av olika molekylära modifikationer kommer vara till stor hjälp för att skapa nya hartssyror med ökad effekt och selektivitet för olika jonkanaler i framtiden. 


\section{LIST OF ARTICLES}

This thesis is based on the following articles, referred by their roman numerals:

I. Ottosson, N. E., Silverå Ejneby, $\mathbf{M}^{*}$., Wu, X*, Yazdi, S., Konradsson, P., Lindahl, E., and Elinder, F. (2017) A drug pocket at the lipid bilayerpotassium channel interface. Science Advances 3(10): e1701099

II. Silverå Ejneby, M., Wu, X., Ottosson, N. E., Münger, E. P., Lundström, I., Konradsson, P., and Elinder, F. (2018) Atom-by-atom tuning of the electrostatic potassium-channel modulator dehydroabietic acid. Journal of General Physiology 150(5): (In press)

III. Salari, S., Silverå Ejneby, M., Brask, J., and Elinder, F. (2018) Isopimaric acid - a multi-targeting ion channel modulator reducing excitability and arrhythmicity in a spontaneously beating mouse atrial cell line. Acta Physiologica 222(1): 12895

* Equal contribution 


\section{INTRODUCTION}

This thesis deals with voltage-gated ion channels that underlie the electrical activity in the heart and brain, and with the development and characterization of small-molecule compounds that can be used to open or close voltage-gated ion channels. Voltagegated ion channels have long been used as pharmacological targets for many types of diseases, even before we knew they existed, in particular for diseases of excitability, such as epilepsy, cardiac arrhythmia, and for pain. Still, new drugs are needed because the existing drugs do not adequately help all patients, and some drugs also cause severe side effects. In the research leading to this thesis I have characterized how resin acids, naturally occurring components of pine resins, can be used to regulate the opening and closing of voltage-gated ion channels. Before going into much more detail, I describe the role of ion currents in the brain and heart, the structure and gating of voltage-gated ion channels, and how these have been, and can be, used as pharmacological targets.

\section{lons underlie the electrical activity in the heart and brain}

In the late $18^{\text {th }}$ century, Luigi Galvani described the role of electricity in muscle movement (Galvani, 1791), followed by others, who made current measurements in the heart (Kölliker and Müller, 1856; Matteucci, 1842) and nerves (Du Bois-Reymond, 1849). Later, Ringer showed that sodium $\left(\mathrm{Na}^{+}\right)$, potassium $\left(\mathrm{K}^{+}\right)$, and calcium $\left(\mathrm{Ca}^{2+}\right)$ were needed to maintain a normal heartbeat, and in his papers he raised a thought about ion selectivity, since $\mathrm{Na}^{+}$did not affect the "refractoriness" of the heart to the same extent as $\mathrm{K}^{+}$(Ringer, 1882b, 1882a, 1883). The ionic origin behind the electrical activity was further speculated when Nernst worked with diffusion of electrolytes in solutions and described Nernst's equation (Nernst, 1889). Bernstein also suggested in his "Membrane theory" from 1902 (Bernstein, 1902) that the cell membrane was permeable to $\mathrm{K}^{+}$in its resting state (inspired by the work of Nernst), and that the permeability changed during an electric impulse. With these articles, and others not mentioned here, a connection between ions and electrical activity in the heart and brain had been suggested. This would soon start a new era.

\section{A mathematical model for the nerve impulse - Hodgkin and Huxley}

In the 1930s, Young introduced the use of the squid's giant axon as providing a unique opportunity to study the function of nerve cells because of the axon's enormous size (50-1000 times larger diameter than other neurons, $1 \mathrm{~mm}$ ) (Hille, 2001; Young, 1936, 1938). Most outstandingly, Hodgkin and Huxley used the giant axon to study the relationship between ion currents and membrane voltage of a nerve in a series of papers, using the voltage-clamp technique (Hodgkin and Huxley, 1952a, 1952b, 1952c; Hodgkin and Katz, 1949; Hodgkin et al., 1952) for which they shared the Nobel Prize in Physiology or Medicine 1963. In their final paper they impressively (!) described a mathematical model for the nerve impulse (Hodgkin and Huxley, 1952d), with the 
underlying currents described in four parts; a capacitive current, a $\mathrm{Na}^{+}$current, a $\mathrm{K}^{+}$ current, and a leak current, summarized in the following equation:

$C_{m} \frac{d V}{d t}=I_{\text {stim }}-g_{N a} m^{3} h\left(V-V_{N a}\right)-g_{K} n^{4}\left(V-V_{K}\right)-g_{\text {leak }}\left(V-V_{\text {leak }}\right)$

In this equation, $\mathrm{V}$ is the membrane potential, $\mathrm{C}_{\mathrm{m}}$ is the membrane capacitance $\left(1 \mu \mathrm{F} / \mathrm{cm}^{2}\right)$, $I_{\text {stim }}$ the stimulation current, $V_{x}$ and $g_{x}$ the reversal potential and the maximal conductance for each current, respectively.

The leak conductance is assumed to be constant, and the gates that control the $\mathrm{Na}^{+}$ and $\mathrm{K}^{+}$conductance are the $\mathrm{m}$-gate (activation of $\mathrm{Na}^{+}$channels), h-gate (inactivation of $\mathrm{Na}^{+}$channels), and n-gate (activation of $\mathrm{K}^{+}$channels). The gates are both time- and voltage dependent, as summarized by the equation below:

$$
\frac{d y}{d t}=\alpha_{y}(V)(1-y)-\beta_{y}(V) y
$$

where $\alpha$ and $\beta$ describe the voltage dependent transition rates between a permissive and nonpermissive state, and $\mathrm{y}=[\mathrm{m}, \mathrm{h}, \mathrm{n}]$ is a dimensionless variable that describes the probability (between 0 and 1 ) for a gate to be in a certain permissive state.

A

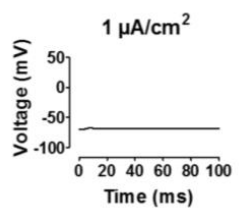

B

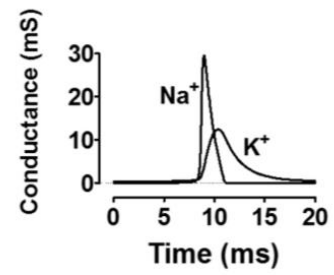

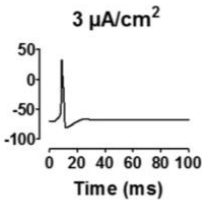
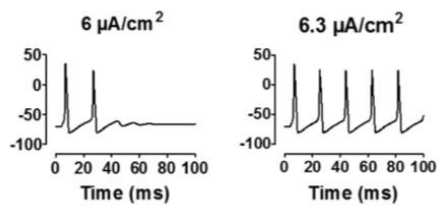

C

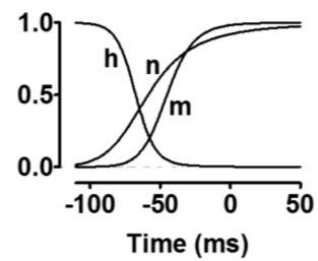

Figure 1. Hodgkin and Huxley model. A) Action potentials elicited under continuous current stimuli B) Conductance of $\mathrm{Na}^{+}$and $\mathrm{K}^{+}$ions during an action potential. C) Voltage dependence for the $\mathrm{m}$ - $\mathrm{h}$ - and $\mathrm{n}$-gate. Simulations were made in Matlab.

In figure $1 \mathrm{~A}$, action potentials elicited from a nerve cell are shown when different stimulating currents are applied, using the Hodgkin-Huxley model. The nerve impulse (action potential) begins once the inward current exceeds the outward current, as the $\mathrm{Na}^{+}$channels open (Figure $1 \mathrm{~B}-\mathrm{C}$ ). The fast influx of $\mathrm{Na}^{+}$makes the cell more positive on the inside (depolarization), but only for a short while since $\mathrm{Na}^{+}$channels inactivate rapidly and $\mathrm{K}^{+}$channels start to open (with a short delay, Figure $1 \mathrm{~B}-\mathrm{C}$ ). The outflux of $\mathrm{K}^{+}$then makes the cell more negative on the inside (repolarization) until the membrane potential reaches its resting state again $(-70 \mathrm{mV})$. 


\section{Cardiac action potentials - a great diversity of shapes}

Cellular cardiac electrophysiology began in the 1950 s when fine-tipped micropipettes were used to record action potentials (Coraboeuf and Weidmann, 1949; Hutter and Trautwein, 1956; Woodbury et al., 1950, 1951). The cardiac action potentials had much longer duration ( $\sim 300 \mathrm{~ms})$ than those recorded from nerve cells (1-2 ms) and in 1962 Denis Noble made the first mathematical description of a cardiac action potential, by modifying the Hodgkin-Huxley model (Noble, 1962). The major difference was that the voltage-dependent $\mathrm{K}^{+}$current was now described as two separate currents ( $\mathrm{IK}_{\mathrm{K}}$; inward rectifier and $\mathrm{I}_{2}$; delayed rectifier), but two years later there was evidence for an inward $\mathrm{Ca}^{2+}$ current that maintained the depolarization of the action potential (Beeler and Reuter, 1970; Katz and Repke, 1966; Niedergerke and Orkand, 1966; Reuter, 1966).

Cardiac electrophysiology (and the entire field of electrophysiology) was then taken to even greater heights when Neher and Sakmann developed the patch-clamp technique (Hamill et al., 1981; Neher and Sakmann, 1976; Sakmann and Neher, 1984), for which they shared the Nobel Prize in Physiology or Medicine 1991. The technique allowed researchers to measure the opening and closing of single ion channels and more accurately control the voltage over the membrane for smaller cells. Today it is well established that the function of the heart is dependent on distinct electrophysiological properties of the heart cells in the various regions of the heart (Bartos et al., 2015; Danielsson et al., 2013; Nerbonne and Kass, 2005). This type of variation arises because the macroscopic $\mathrm{Na}^{+}, \mathrm{K}^{+}$and $\mathrm{Ca}^{2+}$ currents are controlled by the activation and inactivation of many types of ion channels, with different expression patterns in the heart. The structure and gating of these voltage-gated ion channels are discussed below.

\section{Voltage-gated ion channels}

The human genome encodes for $\sim 140$ voltage-gated ion channels ( $\mathrm{Yu}$ and Catterall, 2004) that have different expression patterns in various cellular and subcellular compartments (Biel et al., 2009; Birnbaum et al., 2004; Catterall, 2000, 2011; Nerbonne and Kass, 2005; Vacher et al., 2008), and the expression also changes during development (Danielsson et al., 2013; Thompson et al., 2014; Tyser et al., 2016). The structure of voltage-gated ion channels is known from many experimental and structural studies that have been reviewed in detail previously (Börjesson and Elinder, 2008; Catterall et al., 2017; Yu and Catterall, 2004). In the following section, I will mainly highlight the structure of the voltage sensor and its movement during ion-channel gating since these have played a central role for my research. 


\section{General structure}

Generally, a voltage-gated ion channel has a central pore (Figure 2A), with a selectivity filter in the middle so that only certain ions can pass, and an internally located activation gate that regulates the flow of ions. The pore is surrounded by four voltage sensor domains (VSDs; Figure 2A), that are coupled to the pore via the $\mathrm{S}_{4}-\mathrm{S}_{5}$ linker (Börjesson and Elinder, 2008; Catterall et al., 2017; Long et al., 2007; Sun and MacKinnon, 2017). Voltage-gated potassium ( $\mathrm{KV}_{\mathrm{V}}$ ) channels and cyclic nucleotide activated (CNG) channels are examples of ion channels that are assemblies of four subunits ( $\alpha$-subunits). The subunits can either be encoded by the same gene, as for the Shaker Kv channel (Tempel et al., 1987; Timpe et al., 1988), or different genes, as for the M-type $\mathrm{Kv}_{v}$ channel (Kv7.2/7.3; KCNQ3 and KCNQ2) (Brown and Adams, 1980; Wang et al., 1998). Voltage-gated sodium (Nav) channels and voltage-gated calcium (Cav) channels, on the other hand, consist of one single protein with four non-identical motifs (I-IV) (Noda et al., 1984; Payandeh et al., 2011; Takahashi et al., 1987; Tanabe et al., 1987; Wu et al., 2016).

A

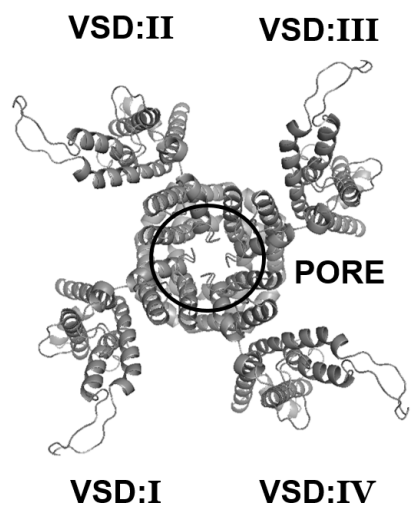

B

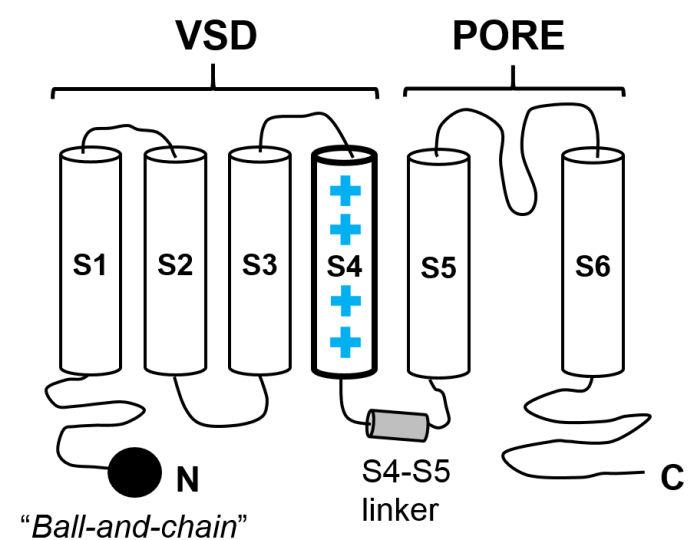

Figure 2. A) Top view of a $K_{v}$ channel, from the extracellular side of the membrane. VSD: Voltage sensor domain. The black ring highlights the pore. B) Schematic illustration of an $\alpha$-subunit of a $K_{v}$ channel.

Regardless of how the voltage-gated ion channel is assembled, the subunits or motifs have six transmembrane segments (S1-S6) (Figure 2B). Helices S1-S4 from one subunit/motif make up one VSD, and S5-S6 from all four subunits/motifs together form the central pore. Voltage-gated ion channels can also co-assemble with $\beta$ subunits that modulate ion channel characteristics such as membrane expression and ion-channel gating (Campiglio and Flucher, 2015; Isom et al., 1992, 1995), and also pharmacological sensitivity (Liin et al., 2015; Sun et al., 2007; Yu et al., 2013).

\section{Gating charges on the voltage sensor}

Hodgkin and Huxley predicted that charges have to move between a permissive and non-permissive state, to open or close the ion-conducting gate, in response to changes in membrane potential (Hodgkin and Huxley, 1952d). Therefore, the S4 segments in the VSDs, were recognized early as candidates for voltage sensing (Catterall et al., 
1986; Noda et al., 1984; Stühmer et al., 1989), since they have several positively charged amino acid residues located along the transmembrane segment (Figure 2B). Today it is known that when the positively charged residues, called gating charges (Armstrong and Bezanilla, 1974; Keynes and Rojas, 1974), move in the electric field they transfer the electrically driven conformation changes to surrounding protein structures to control the opening and closing of voltage-gated ion channels.

The Shaker Kv channel, which has been used as a model channel in my research, is normally expressed in the nervous system of the fruit fly, Drosophila melanogaster (Kaplan and Trout, 1969). It was the first Kv channel to be cloned (Kamb et al., 1987; Papazian et al., 1987; Pongs et al., 1988; Tempel et al., 1987) and is one of the best characterized ion channels today. The Shaker $\mathrm{K}_{\mathrm{V}}$ channel has seven positively charged amino acids on the voltage sensor ( 5 arginies, 2 lysines). Surrounding countercharges in transmembrane segments S1- S3 (Keynes and Elinder, 1999; Lecar et al., 2003; Long et al., 2007; Papazian et al., 1995) assist in the transfer of these positive charges as the voltage sensor moves inside the lipid bilayer, approximately $12 \AA$ relative to the rest of the VSD (Henrion et al., 2012). However, among the family of voltage-gated ion channels, the number of gating charges on the voltage sensor, and their distribution in 3D space varies (Börjesson and Elinder, 2008; Keynes and Elinder, 1999).

\section{A channel closed, open and inactivated}

The gating of the Shaker $\mathrm{K}_{V}$ channel involves the processes of opening, inactivation, and deactivation (Figure 3). This will be described to some extent in relationship to the Nav - and Cav channels in next sections.

\section{Opening}

The voltage sensor $\mathrm{S} 4$, with its positively charged amino-acid residues, is kept in a 'down' position at resting membrane potential (Figure 3, left). Depolarization of the cell then drives the voltage sensor to an 'up' position (Figure 3, center), since it becomes more positively charged on the inside of the cell (Catterall et al., 2017; Henrion et al., 2012; Vargas et al., 2012). For the Shaker $\mathrm{K}_{\mathrm{V}}$ channel, the four voltage sensors first move up independent from each other, in several activation steps, and then together in a last cooperative step, to the final 'up-state' (Börjesson and Elinder, 2011; Henrion et al., 2012; Pathak et al., 2005). This opens the internally located activation gate, because the voltage sensors pull on the $\mathrm{S}_{4}-\mathrm{S}_{5}$ linkers. The opening of Nav channels is similar (Catterall et al., 2017), but the voltage sensors from the four 


\section{Closed}

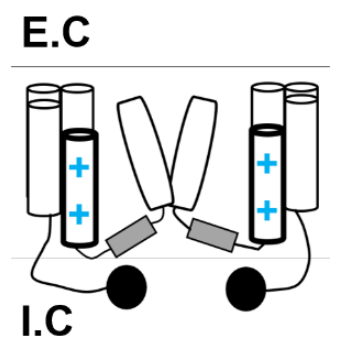

Open

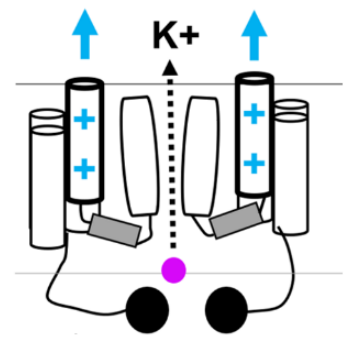

Inactivated

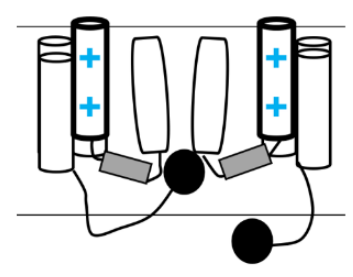

Figure 3. Gating of the Shaker Kv channel, illustrative figure.

motifs activate in a specific voltage- and time- dependent sequence before the gate opens (III $>$ I $>$ II $\gg$ IV; (Chanda and Bezanilla, 2002)). A sequential movement of the voltage sensors has also been recognized for Cav channels (Pantazis et al., 2014), although with some dissimilarities from the Nav channels.

\section{Fast inactivation}

A-type $\mathrm{K}_{\mathrm{v}}$ channels (including the unmodified Shaker $\mathrm{K}_{\mathrm{V}}$ channel, see methods), Nav channels and Cav channels inactivate rapidly (within milliseconds) after the pore has opened (Armstrong, 1969; Armstrong and Bezanilla, 1977; Armstrong et al., 1973; Bezanilla and Armstrong, 1977). The fast inactivation, called N-type inactivation (Hoshi et al., 1990), is for the Shaker Kv channel attributed to amino acids in the Nterminus of the a-subunit, which form a "ball-and-chain" structure (Figure 3, right). This structure folds towards the pore and blocks the ion conducting pathway, and it is believed that only one "ball-and-chain" structure block the pore at a given time (MacKinnon et al., 1993). For Nav channels the loop between motif III and IV forms the N-type inactivation gate (Stühmer et al., 1989; Vassilev et al., 1989, 1988; West et al., 1992), and the voltage sensitivity of the inactivation is mainly attributed to the voltage-sensor movement of motif IV (Armstrong and Hollingworth, 2017; Chen et al., 1996; Keynes and Elinder, 1998). For Cav channels the loop between motif I and II appears to be a key structure for the inactivation (An and Zamponi, 2013). Other loops and peptide segments have also been reported to be involved in the inactivation, both for Nav channels (Catterall, 2000) and Cav channels (An and Zamponi, 2013).

\section{Slow inactivation}

There is also a slower type of inactivation (within hundreds of milliseconds to seconds), called C-type inactivation, that occurs after prolonged depolarization (Choi et al., 1991; Conti et al., 2016; Hoshi et al., 1991; Payandeh et al., 2012; Rudy, 1978). The slow inactivation is caused by a rearrangement of the selectivity filter (Armstrong and Hollingworth, 2017; Hoshi and Armstrong, 2013; Perozo et al., 1993; Starkus et 
al., 1997), but the details regarding the protein rearrangement during slow inactivation are not fully understood. Recently, a reciprocal communication between the pore domain and the VSDs on the extracellular side of the Shaker $\mathrm{K}_{\mathrm{V}}$ channel, occurring during slow inactivation, was shown by our research group (Conti et al., 2016).

\section{Deactivation}

When the cell becomes more negatively charged on the inside again, during repolarization, S4 moves down to its original 'down' position. The inactivation gate is removed, and the pore closes when the voltage sensor no longer pulls on the $\mathrm{S}_{4}-\mathrm{S}_{5}$ linker. The rate of the deactivation can vary depending on the preceding voltage, which cause a so called 'mode-shift', that is common for many channels (Elinder et al., 2006; Labro et al., 2012; Villalba-Galea, 2016).

\section{Voltage-gated ion channels as pharmacological targets}

Drugs that act on voltage-gated ion channels have for long been used as a treatment for many diseases, even before we knew such channels existed, in particular to control diseases of excitability (Brodie, 2010; Karagueuzian et al., 2017). Historically, natural compounds found in plants and toxins from animals have also been used to gain a better understanding of the structure and function of voltage-gated ion channels (Agnew et al., 1978; Cestèle and Catterall, 2000; MacKinnon, 1991; Stevens et al., 2011). From a clinical perspective, drugs that block Nav and Cav channels have classically been used to reduce the cellular excitability in diseases such as epilepsy, pain and cardiac arrhythmia (Bagal et al., 2015; Brodie, 2017a; Fozzard et al., 2011; Merritt and Putnam, 1938). The binding site for Nav channel blockers, such as local anesthetics and related compounds, are located in the intracellular part of the pore domain, but at least six different binding sites for neurotoxins (that block the pore or alter the channels the voltage dependence) have been described as well (Catterall and Swanson, 2015). The most widely used Cav channel blockers bind to the intracellular gate in a state-dependent manner (i.e. with higher or lower affinity to the opened, closed or inactivated channel) (Zamponi et al., 2015). However, many of the older drugs do not selectively target one type of voltage-gated ion channel, which contributes in some part to their efficacy, but it also increases the risk for side effects (Bagal et al., 2015; Brodie, 2017b; Rolf et al., 2000; Stas et al., 2016; Zamponi et al., 2015). In addition, many patients do not respond adequately to treatment: for example $30 \%$ of the 65 million people with epilepsy do not become seizure free using any of the existing drugs (Moshé et al., 2015).

More recently, the opening of $\mathrm{Kv}$ channels has emerged as an alternative means to reducing cellular excitability and/or to controlling the duration of repolarization (Humphries and Dart, 2015; Liin et al., 2016a; Peretz et al., 2005, 2007; Tigerholm et al., 2012; Wulff et al., 2009; Xiong et al., 2008), since only small changes in the voltage dependence of activation of $\mathrm{K}_{\mathrm{v}}$ channels would be needed to reduce cellular excitability (Figure 4). However, considering the clinical impact that $\mathrm{Kv}$ channel modulators could 
have, due the diversity of $\mathrm{K}_{V}$ channels and their defined tissue distribution, $\mathrm{K}_{\mathrm{V}}$ channels remain relatively unexploited as drug targets. One challenge is attributed to the ability of $\mathrm{K}_{\mathrm{V}}$ channel $\alpha$-subunits to form heterotetrametric channels and their association with auxiliary $\beta$-subunits, but it has also been challenging to find selective drugs that target one type $\mathrm{K}_{v}$ channel.
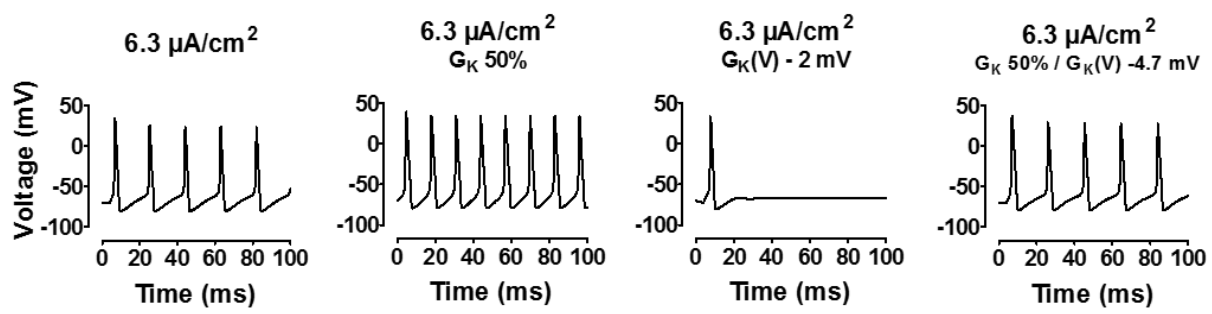

Figure 4. Action potentials elicited from the Hodgkin and Huxley model under continuous current stimuli, before and after $G_{k}$ has been reduced by $50 \%$, or the voltage dependence of $G_{k}$ has been shifted towards more negative membrane voltages, alone or in combinations with each other. Simulations were made in Matlab.

\section{Polyunsaturated fatty acids}

The 3R (M356R, A359R, R362) Shaker Kv channel (Figure 5A), with two additional positively charged residues at the end of the voltage sensor, was systematically constructed in our research group to search for new compounds that could open $\mathrm{KV}$ channels (Ottosson et al., 2014), in a manner similar to that of polyunsaturated fatty acids (PUFAs). PUFAs open the WT and $3 \mathrm{R}$ Shaker $\mathrm{Kv}$ channel (Börjesson and Elinder, 2011; Börjesson et al., 2008, 2010; Elinder and Liin, 2017; Ottosson et al., 2014; Xu et al., 2008), and the human Kv7.1 and Kv7.2/7.3 channel (Liin et al., 2015, 2016a, 2016b), via an electrostatic mechanism of action, exerted on the positively charged voltage sensor $\mathrm{S}_{4}$ (Figure $5 \mathrm{~B}$ ). The negatively charged carboxyl group facilitate the outward movement of the voltage sensor, in the final opening step, and as consequence the $\mathrm{Kv}$ channels open at more negative membrane potentials (Figure ${ }_{5} \mathrm{C}$ ) (Börjesson et al., 2008, 2010; Liin et al., 2015, 2016b). The hydrophobic tail, with at least two double bounds in cis-configuration, is needed for anchoring the PUFA close to the voltage sensor. Because both a hydrophobic tail and a charge are needed for the effect it has been referred to as the lipoelectric mechanism of action (Börjesson et al., 2008). This mechanism has recently been reviewed in detail together with the effects of PUFAs on several other voltage-gated ion channel (Elinder and Liin, 2017). 
A

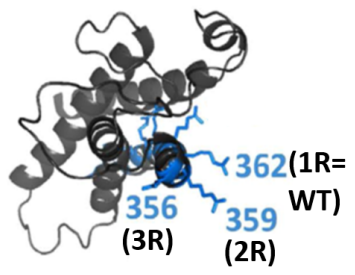

B

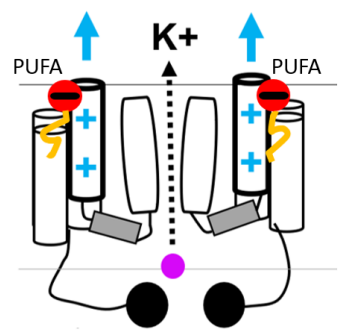

C

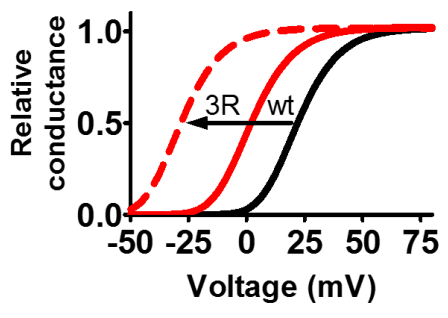

Figure 5. A) Top view VSD. 3R Shaker KV channel. B) PUFAs electrostatically interact with the voltage sensor C) PUFAs shift the $G(V)$ curve of the WT (red line) and 3R Shaker KV channel (red dotted line), illustrative figure

\section{Resin acids}

In the search for new compounds that could open $\mathrm{KV}_{\mathrm{V}}$ channels, using the $3 \mathrm{R}$ Shaker $\mathrm{Kv}$ channel, resin acids, natural components of pine resin, such as dehydroabietic acid (DHAA), abietic acid (AA) and isopimaric acid (IPA) (Figure 6A), were found to have a potential for use (Ottosson et al., 2014, 2015). They shift the voltage-versusconductance $[G(V)]$ curve of the WT and ${ }_{3} \mathrm{R}$ Shaker $\mathrm{Kv}_{\mathrm{v}}$ channel in the negative direction along the voltage axis. This effect can be increased by modifying the hydrophobic three-ringed motif, with halogenation of the C-ring, and small non-polar side chains at $\mathrm{C}_{7}$ on the B-ring (Figure 6B) (Ottosson et al., 2015). In addition, some resin acids also open big-conductance $\mathrm{Ca}^{2+}$-activated $\mathrm{K}^{+}$channels (BK) channels (Cui et al., 2008, 2010, 2016; Gessner et al., 2012; Imaizumi et al., 2002; Ohwada et al., 2003; Sakamoto et al., 2006; Tashima et al., 2006). However, neither the binding site for resin acids to the Shaker Kv channel nor the details about the molecular interaction between the resin acid and the Shaker $\mathrm{Kv}_{\mathrm{v}}$ channel were known at that time. The need to understand these led to setting goals for the research leading to this thesis.

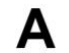

DHAA<smiles>CC(C)c1ccc2c(c1)CC[C@H]1[C@@H]2[C@@]2(C)CCC[C@@]1(C)C(=O)O2</smiles>

AA

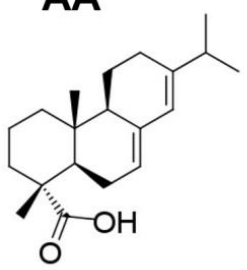

IPA

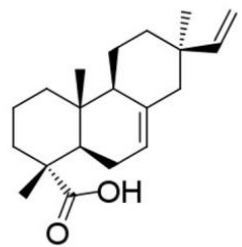

B

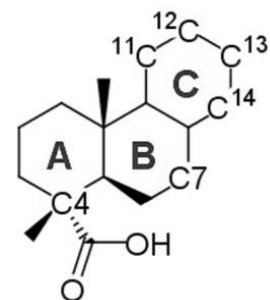

Figure 6. A) Molecular structure of three naturally occurring resin acids: Dehydroabietic acid (DHAA), Abietic acid (AA) and Isopimaric acid (IPA). B) Nomenclature for the resin acid molecule. 


\title{
AIMS OF THE RESEARCH
}

The general aim of this thesis was to characterize and modify new small-molecule compounds that target voltage-gated ion channels. The specific aims are listed below:

\section{$\operatorname{Aim} 1$}

Characterize the binding site and mechanism of action of resin acids on the Shaker $\mathrm{Kv}$ channel (Articles I and II)

\begin{abstract}
$\operatorname{Aim} 2$
Explore the role of the position and the valence of the effector (= carboxyl group) for a resin acid (Article II)
\end{abstract}

\section{$\operatorname{Aim} 3$}

Test the effect of resin acids on the human M-type $\mathrm{Kv}_{v}$ channel (hKv7.3/7.3), which is an important target for anti-epileptic drugs (Article II)

\section{$\operatorname{Aim} 4$}

Test the effect of a resin acid on cardiac excitability and the effect on several voltagegated ion channels expressed in cardiomyocytes (Article III) 


\section{METHODOLOGY}

Below follows a brief description of cell types, electrophysiological techniques, ion channels, protocols and analysis methods that have been used, for the general understanding. Details can be found in the method section of each article.

\section{Cell types}

\section{Xenopus laevis oocytes}

The African clawed frog, Xenopus laevis, oocyte system has been widely used to study ion channels since it was first used in pioneer studies in 1971 (Gurdon et al., 1971). The system is useful for studying the correlation of molecular structure and electrophysiological function of ion channels, but also for screening of potential drug candidates that target ion channels (Goldin, 2006). Oocytes in development stage VVI (in total I-VI stages) are large ( $\sim 1 \mathrm{~mm}$ in diameter), so they are easy to handle, and one can insert electrodes into the oocyte to make electrophysiological measurements without difficulties. Further advantages are that the oocytes can translate injected mRNA from several species and target the protein(s) to the correct subcellular compartment in large quantities (Gurdon et al., 1971). The oocytes also have a low expression of endogenous ion channels, and the ratio of injected RNA can easily be adjusted, as for the human M-type $\mathrm{Kv}$ channel when one injects both Kv7.2 and Kv7.3 subunits.

The protocol for preparing oocytes for electrophysiological measurements has been describe in detail before (Börjesson et al., 2010; Ottosson et al., 2015). Briefly, it involves surgery of anesthetized frogs (Etyl 3-aminobenzoate metanesulfonate salt; Tricaine) to harvest oocytes in large quantities, enzymatical treatment of oocyte lobes (Liberase), injection of cRNA into the oocytes and incubation for 1-3 days, before the ion channels are expressed in large quantities in the membrane of the oocytes.

\section{HL-1 cells}

The HL-1 cardiomyocyte cell line is derived from the AT- 1 mouse atrial cardiomyocyte tumour lineage. It is the only cardiac cell line that contracts spontaneously and maintain cardiac-specific phenotypes, such as morphology, biochemical and electrophysiological properties, after several passages, while it also can be recovered from frozen stocks (Claycomb et al., 1998). The HL-1 cells exhibit spontaneous action potentials and synchronous beating in confluent cell cultures. Two types of action potentials can be found, one with a slow depolarization phase before the rapid upstroke, and one without (Sartiani et al., 2002).

Depolarizing currents found in HL-1 cells include the sodium current ( $\mathrm{I}_{\mathrm{Na}}$ ) (Strege et al., 2012), the funny current (If), which is expressed in approximately $30 \%$ of the cells ( $\mathrm{HCN}_{1}$ and $\mathrm{HCN} 2$ isoforms is expressed in a larger amount than $\mathrm{HCN}_{3}$ and $\mathrm{HCN}_{4}$ isoforms) (Sartiani et al., 2002), and the L-type calcium current (ICaL) (Lu et al., 2016). 
A subgroup of HL-1 cells also have a T-type calcium current ( $\mathrm{I}_{\mathrm{CaT}}$ ) in the absence of $\mathrm{I}_{\mathrm{CaL}}$ (Yang et al., 2005). The most prominent repolarizing current in HL-1 cells is the rapid delayed rectifier current ( $\mathrm{I}_{\mathrm{Kr}}$ ) (Claycomb et al., 1998), but other potassium currents are also found as well, including the transient outward ( $\mathrm{Ito}_{\mathrm{to}}$ current (Lu et al., 2016), which was measured as described in Article III (with the other ion currents described above as well). The HL-1 cells were cultured according to protocol provided with the cells (Claycomb et al., 1998).

\section{Electrophysiological techniques}

The voltage-clamp technique that was developed by Marmont, Cole, Hodgkin, Huxley, and Katz (Hille, 2001), can be used to study voltage-gated ion channels. It allows the membrane potential to be set at a command voltage, and the current that flows across the membrane can then be measured at that particular voltage. The voltage is kept constant over time with a current electrode, which adjusts for changes in the membrane potential, for example when ion channels open. Two different techniques were used to clamp the membrane voltage (described below). The patch-clamp technique was also used to measure spontaneous action potentials elicited form HL-1 cells (current injection $=0$ ).

\section{Two-electrode voltage-clamp technique}

The Two-electrode voltage-clamp (TEVC) technique is commonly used to study voltage-gated ion channels expressed in Xenopus laevis oocytes. This technique is favoured when measuring large currents since it has a high current-passing capacity that cannot be achieved with the singleelectrode patch-clamp technique. TEVC is carried out by inserting two electrodes into the oocyte (Figure 7). The voltage electrode and the reference electrode measure the voltage across the membrane. If there is a deviation from

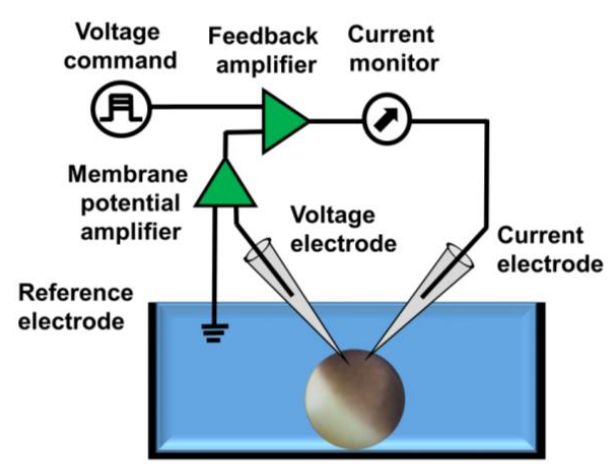

Figure 7. Illustrative figure of the two-electrode voltage-clamp technique. the command voltage this is corrected by the current electrode. The flow of ions is then registered by the amplifier as an inward or outward going current.

\section{Patch-clamp technique}

The advantage of the patch-clamp technique, over the TEVC technique, is that it allows electrophysiological measurements from small cells, or even a patch of the membrane. In Article III, the whole cell configuration of the patch-clamp technique was used (Hamill et al., 1981). A fluid-filled micropipette, containing an $\mathrm{Ag} / \mathrm{Cl}-$ electrode, is brought into contact with the cell membrane and a giga-seal is formed. Further suction 
ruptures the patch of membrane, which provides access to the inside of the cell. The patch-clamp technique is based on the same principle as the voltage-clamp technique and uses a feedback system where the command voltage is compared with membrane potential, and if there is deviation a current is injected. This method was also used to measure spontaneous action potentials (current injection $=0$ ), from HL-1 cells.

\section{Protocols and Analysis}

\section{Kv channels expressed in oocytes}

Expression of ion channels

In Articles I and II, the WT Shaker $\mathrm{Kv}_{\mathrm{v}}$ channel, several mutated Shaker $\mathrm{Kv}_{\mathrm{v}}$ channels, and the human M-type $\mathrm{K}_{\mathrm{v}}$ channel (hKV7.2/7.3) were expressed in Xenopus laevis oocytes (1-6 days after RNA injection). To remove the fast inactivation of the Shaker $\mathrm{Kv}$ channel a deletion of 40 amino acids in the N-terminus was made (Hoshi et al., 1990). Point mutations around at $\mathrm{S}_{3}, \mathrm{~S}_{4}$, and the $\mathrm{S}_{3}-\mathrm{S}_{4}$ linker of the Shaker $\mathrm{Kv}$ channel were introduced using site-directed mutagenesis. All S4 mutants of the Shaker $\mathrm{Kv}$ channels have been characterized before and have been used to study the effect of PUFAs (Ottosson et al., 2014). For separating the last opening step from the early activation steps (Article $I$ ) the ILT Shaker mutant (V369I, I372L, and S376T), was used, since it makes the last opening step rate limiting (Ledwell and Aldrich, 1999; Smith-Maxwell et al., 1998). For measuring the early activation steps the W434F-ILT Shaker mutant (C245V, V369I, I372L, S376T, C426A, W434F) was used, because the $\mathrm{W} 434 \mathrm{~F}$ mutation remove the ion conduction (completely C-type inactivated) without affecting the gating currents (Perozo et al., 1993; Yang et al., 1997). The human M-type $\mathrm{Kv}$ channel was expressed by co-injection of hKv7.3 and hKv7.2 in a 1:1 ratio (Liin et al., 2016b).

\section{Voltage protocols}

For the WT Shaker $\mathrm{Kv}$ channel, and the majority of the Shaker $\mathrm{Kv}$ channel mutants, the holding potential was set to $-80 \mathrm{mV}\left(-120 \mathrm{mV}\right.$ for the $\mathrm{L} 361 \mathrm{R} / \mathrm{R}_{3} 62 \mathrm{Q}$ Shaker mutant). At this membrane potential all $\mathrm{Kv}$ channels are closed. The voltage was then increased in $5 \mathrm{mV}$ steps to $50 \mathrm{mV}$ (WT Shaker) or $70 \mathrm{mV}$ ( 3 R Shaker). The ILT mutant, that isolates the last opening step from the preceding activations steps, opens more slowly and at even more positive membrane potentials. To account for this, the duration of the voltage protocol was increased, and the currents were measured up to $160 \mathrm{mV}$. For most Shaker channels, the closing was measured at $-20 \mathrm{mV}$, after the depolarizing steps described above. To study the closing kinetics in detail for some of the compounds the channels were first opened with a pre-pulse to 50 or $70 \mathrm{mV}$, followed by $5 \mathrm{mV}$ steps down to $-100 \mathrm{mV}$.

The human M-type $\mathrm{K}_{v}$ channel (hKv7.2/7.3), compared to the Shaker $\mathrm{K}_{v}$ channels, opens at more negative membrane potentials, more slowly, and does not inactivate. Therefore, the holding potential was set to $-100 \mathrm{mV}$ and the voltage was clamped 
between -120 and $50 \mathrm{mV}$, in $10 \mathrm{mV}$ increments, for $2 \mathrm{~s}$ (compared with $100 \mathrm{~ms}$ for the Shaker Kv channel). The tail currents were measured at $-30 \mathrm{mV}$ for $1 \mathrm{~s}$.

Data analysis of voltage shifts

To calculate the K conductance for the Shaker K channel the steady-state currents were measured at the end of the test pulse (since the closing of the channels is fast) and the following equation was used;

$$
G_{\mathrm{K}}(V)=I_{\mathrm{K}} /\left(V-V_{\mathrm{K}}\right),
$$

$I_{\mathrm{K}}$ is the steady-state current, $V$ the absolute membrane voltage, and $V_{\mathrm{K}}$ the reversal potential for potassium (set to $-80 \mathrm{mV}$ ).

The K conductance-versus-voltage data was then fitted with a modified Boltzmann curve;

$$
G_{\mathrm{K}}(V)=A /\left(1+\exp \left(\left(V_{1 / 2}-V\right) / s\right)\right)^{n}
$$

$A$ is the amplitude of the curve, $V_{1 / 2}$ the midpoint when $n=1, s$ the slope and $n$ an exponent for better curve fitting.

The shift in the voltage dependence for the Shaker Kv channels was calculated at 10\% of maximal conductance in the control curve (when $n$ was set to 4 for better curve fitting) (Börjesson et al., 2008). $\mathrm{V}_{1 / 2}$ was calculated for the human M-type Kv channel when $\mathrm{n}$ was set to 1 and when the slope was shared between the control curve and the compound curve. Generally, the method of determining the shift is relatively insensitive to the method used as long the compound does not increase the amplitude several magnitudes and does not affect the slope of the curve to a greater extent (which is not the case for our compounds). This has also been discussed before (Börjesson et al., 2008) and in the supplementary information in Article I.

\section{Action potentials and ion currents of cardiomyocytes}

Action potential characteristics

Action potentials were recorded using the patch-clamp technique in normal physiological solution (see method section in Article III for details) when the HL-1 cells were confluent, at $35^{\circ} \mathrm{C}$. We analyzed several action potential characteristics including the resting-membrane potential, action-potential amplitude, maximal-rise slope, maximal-decay slope, action-potential frequency and the action-potential duration at 30,50 and $70 \%$ of the repolarization. This helps to some extent to determine which types of ion channels could be affected by a compound, since they are activated (or inactivated) during different phases of the action potential.

Voltage protocols and solutions for different ion currents

The voltage protocols for measuring different ion currents from HL-1 cells were adjusted for junction potentials. The junction potential arises because ions have different mobility in the interference between the extracellular and intracellular solution, which result in interference when you set the zero-current potential, to which 
the membrane potentials is measured in respect to. Blockers and some modifications of the solutions were also employed to isolate the current of interest: details for this can be found in Article III. The conductance for the currents was calculated using equation 3 and the data was fitted with a modified Boltzmann curve (see Equation 4).

\section{Action-potential simulations}

The Stewart model (Stewart et al. 2009) of a Purkinje fibre cell was used to alter the gating parameters of the ion currents studied in Article III. In this model the cardiomyocyte to excite without an external stimulus and has a total 14 different ionic currents, most of them described with the Hodgkin and Huxley formulation.

$\frac{d V}{d t}=-\left(I_{K 1}+I_{t o}+I_{s u s}+I_{K r}+I_{K s}+I_{C a L}+I_{N a K}+I_{N a}+I_{b N a}+I_{N a C a}+I_{b C a}+\right.$ $\left.I_{p K}+I_{p C a}+I_{f}\right)$

The model was implemented in Matlab from CellML (https://www.cellml.org/) and the model was solved by Matlabs ode15s, which is a time adaptive differential equation solver for stiff equations (such as an action potential with a rapid upstroke and slower repolarization).

\section{Compounds}

Some naturally occurring resin acids are commercial available, including Pimaric acid (PiMA; Alomone Labs), Isopimaric acid (IPA; Alomone Labs), Dehydroabietic acid (DHAA; BOC Science) and Abietic acid (AA; Sigma-Aldrich). All other resin-acid derivatives were synthesized by Xiongyu $\mathrm{Wu}$ and Peter Konradsson at Linköping University, Sweden. The synthesis routine is described in detail in Articles I and II except for Wu5o and Wu 32 (Ottosson et al, 2015). All compounds were dissolved in DMSO $(100 \mathrm{mM}$ or $50 \mathrm{mM})$ and stored at $-20^{\circ} \mathrm{C}$.

Marvin (Marvin 16.12.9; 2016; ChemAxon) was used to for drawing chemical structures and for calculating the $p \mathrm{~K}_{\mathrm{a}}$ and $\log P$ values.

\section{Molecular docking and dynamics simulations}

The crystal structure of the Shaker $\mathrm{K}_{\mathrm{V}}$ channel is not available. All structures of the Shaker $\mathrm{Kv}$ channel have therefore been based on a homology model, made by replacing amino acid residues of the Kv1.2/2.1 channel model (known from the crystal structures) to that of the Shaker $\mathrm{Kv}_{\mathrm{v}}$ channel.

Molecular docking and molecular dynamics simulations in Article I were performed at Stockholm University, Sweden, by Samira Yazdi and Erik Lindahl. One of the most potent compounds, Wu122, was docked to an open-state model of the WT Shaker Kv channel using a single subunit. Three of the top ranked docking-poses were then 
selected for evaluation using molecular dynamics stimulations with the whole Shaker $\mathrm{K}_{\mathrm{V}}$ channel tetramer. More details about the molecular docking can be found in Article I.

\section{Electrostatic model}

Electrostatic energy calculations in Article II were performed by Peter Münger and Ingemar Lundström at Linköping University, Sweden. The electrostatic energy was calculated by treating two charges as point charges in a lipid bilayer (dielectric constant, $\varepsilon_{1}=2$ ) adjacent to water (dielectric constant, $\varepsilon_{2}=80$ ), using the method of image charges ( $=$ the influence of the water is replaced by an image charge for each charge in the membrane). More details about the model and calculations can be found in Article II. 


\section{RESULTS}

\section{Resin acids bind to the Shaker $\mathrm{K}_{v}$ channel in the S3/S4 cleft (Aim 1)}

In Article I we show that resin acids bind between the lipid bilayer and the Shaker $\mathrm{Kv}$ channel, in a pocket between transmembrane segments $\mathrm{S}_{3}$ and $\mathrm{S}_{4}$ of the VSD, on the extracellular side. I describe below the main findings leading to this conclusion.

\section{Resin acids trap S4 in the final 'up-state'}

Many resin acids shift the $G(V)$-curve of WT Shaker $\mathrm{Kv}$ channel in a negative direction along the voltage axis (Ottosson et al., 2015). The $G(V)$-shifting effect is enhanced by the $3 \mathrm{R}$ Shaker $\mathrm{K}_{\mathrm{v}}$ channel (see Figure $5 \mathrm{~A}$ ) that has two extra positively charged arginines at the extracellular end of the voltage sensor (Articles $I$ and $I I$ ). One of the most potent DHAA derivatives (out of 125 in Article I), Wu32 (Figure 8A) was found to slow down the closing kinetics of the WT and ${ }_{3} \mathrm{R}$ Shaker $\mathrm{K}_{\mathrm{V}}$ channel, while it had no effect on the opening kinetics (Figure 1 in Article I). This suggests that $\mathrm{Wu}_{32}$ possibly can bind close to the voltage sensor in the final 'up-state', and from there prevent the downward movement of the voltage sensor, so that the channel is kept open (Figure 8B, Figure $1 \mathrm{G}$ in Article I). In line with this, Wu32 had little effect on the W434F-ILT $Q(V)$ mutant that is used to measure the early voltage-sensor movements (activation steps), while it had a large effect on the ILT $G(V)$ mutant, which is used to measure the last voltage-sensor movement, to the final 'up-state' that opens the ion-conducting pore (Figure $1 \mathrm{H}$ in Article I). The effect of DHAA was also large on the ILT $G(V)$ mutant (Figure $\mathrm{S} 1$ in Article I), suggesting that resin acids act on the voltage sensor, in the final

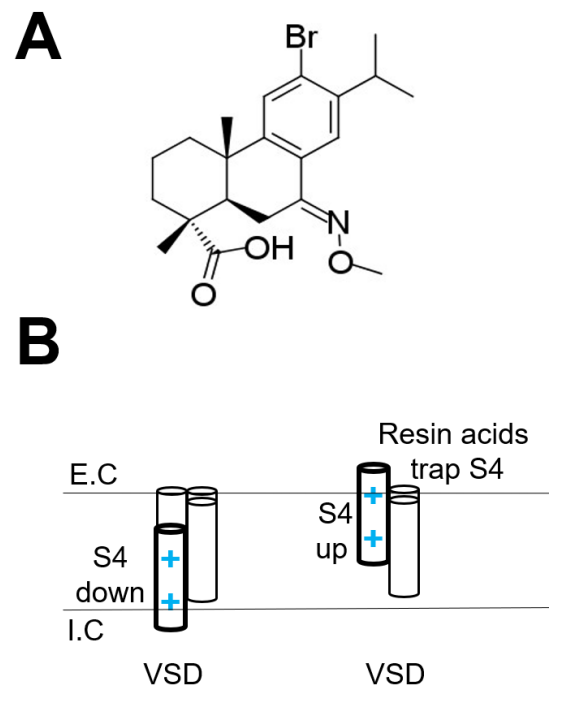

Figure 8. A) Molecular structure Wu32 B) Resin acids trap S4 in the final 'up-state', while it has no effect when S4 'down'.

\section{Resin acids bind in the S3/S4 cleft}

The optimal $\log P$ value for DHAA-derivatives that efficiently open the $3 \mathrm{R}$ Shaker $\mathrm{Kv}$ channel is around 5.5-6.5 (Supplementary Figure S9 in Article I). This demonstrates that the lipophilicity of the resin-acid molecule is important for the effect, and indeed opens up for a binding site to a lipid-exposed protein surface somewhere around the voltage sensor of the Shaker $\mathrm{Kv}$ channel.

A series of cysteine mutations (small polar residues usually not present in the Shaker $\mathrm{Kv}$ channel) was introduced in the extracellular half of $\mathrm{S}_{3}$, to test if resin acids possibly 
could bind between transmembrane segments $\mathrm{S}_{3}$ and $\mathrm{S}_{4}$ of the VSD (lipid-exposed protein surfaces), and from there interact with the voltage sensor in the final 'up-state'. The major finding was that five out of 15 cysteine mutations increased the effect of Wu32 (Figure 2B in Article I). The largest effect was found for $\mathrm{P}_{322 \mathrm{C}}$, that faces the $\mathrm{S}_{3} / \mathrm{S}_{4}$ cleft. A small cysteine at this site increased the effect, and a bulkier residue ( $\mathrm{P}_{322 \mathrm{~W}}$ ), expected to make the pocket smaller, decreased the effect, for both DHAA and Wu32 (Figure 2D in Article I). It is therefore likely that resin acids interact with the voltage sensor from the pocket in the $\mathrm{S}_{3} / \mathrm{S}_{4}$ cleft.

\section{Effective resin acids slow down channel closure}

Wu32 has a large effect on the closing kinetics, and no effect on the opening kinetics (Figure $1 \mathrm{~F}$ in Article I), which was a common feature for many of the most efficient DHAA derivatives, and, in particular, for those with a methyloxime at position $\mathrm{C}_{7}$ on the B-ring (Figure 4A-B in Article I). The mother compound DHAA, on the other hand, shifted the opening and closing kinetics (Figure 4A-B in Article I), and the $G(V)$-curve, along the voltage axis equally, which is expected if a compound acts on the voltage sensors via pure electrostatic interactions (Elinder and Arhem, 2003). It is therefore reasonable to assume that some compounds, including $\mathrm{Wu}_{32}$, can have a deeper and/or tighter interaction to the channel in the $\mathrm{S}_{3} / \mathrm{S}_{4}$ cleft. The compound with the largest effect on the closing kinetics, of all resin acids in Article I, was Wu122 (Figure 4C-D in Article I). Therefore, Wu122 was used in the molecular docking simulations, with its potentially tighter interaction with the channel in the $\mathrm{S}_{3} / \mathrm{s} 4 \mathrm{cleft}$.

\section{Molecular-dynamics simulations}

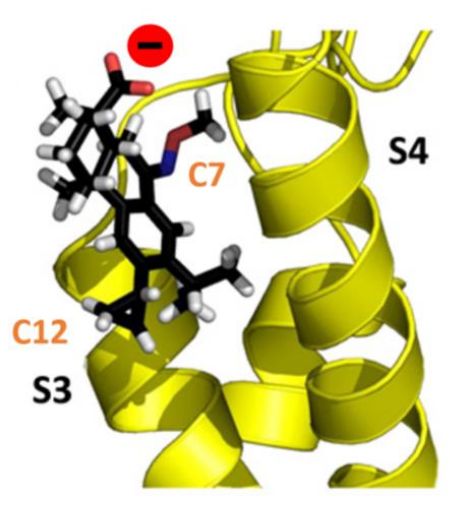

Figure 9 Wu122 bound between transmembrane segments S3 and S4 of the VSD, of the Shaker $\mathrm{K}_{\mathrm{v}}$ channel, Side view.
In the molecular-dynamics simulations, using the complete WT Shaker $\mathrm{K}_{\mathrm{v}}$ channel with several Wu122 molecules placed outside the Shaker subunits, all high-probability interactions between Wu122 and the Shaker $\mathrm{Kv}_{v}$ channel occurred in the $\mathrm{S}_{3} / \mathrm{S}_{4}$ cleft. The Wu122 molecule positioned itself close to the $\mathrm{S}_{3}-\mathrm{S}_{4}$ linker in the lipid bilayer (Figure 9), with the methyloxime at $\mathrm{C}_{7}$ pointing towards $\mathrm{S}_{3}$ and $\mathrm{S}_{4}$, the cyclopropyl at C12 pointing out towards the lipid bilayer and the charged carboxyl group pointing upwards (Figure 5 in Article I). If the charged carboxyl group is buried in the membrane, the compound reorients, so that the charge points upward. Thus, the hydrophobic three-ringed motif seems to be important for anchoring the compound in the lipid bilayer.

Hence, we suggest in Article I that resin acids bind between the lipid bilayer and the Shaker $\mathrm{K}_{v}$ channel, in a pocket between transmembrane segments $\mathrm{S}_{3}$ and $\mathrm{S}_{4}$ of the VSD, on the extracellular side of the membrane. 


\section{Resin acids act via an electrostatic mechanism (Aim 1)}

The resin acid-induced $G(V)$ shift increases when two extra positively charged aminoacid residues are added at the top of the voltage sensor ( $3 \mathrm{R}$ Shaker $\mathrm{K}_{\mathrm{V}}$ channel). To better understand the interaction between resin acids and the voltage sensor (Articles $I$ and $I I$ ), two different approaches were used. First, we changed the position, and sign of charge of the top gating charge ( $\mathrm{R} 1=\mathrm{R}_{3} 62$, WT Shaker $\mathrm{Kv}$ channel). These types of experiments had previously been proven fruitful when investigating the effect of PUFAs that electrostatically interact with the voltage sensor of the Shaker $\mathrm{Kv}$ channel, from the extracellular side of the lipid bilayer (Börjesson and Elinder, 2011; Ottosson et al., 2014). Secondly, we also investigated the role for the resin-acid charge (=carboxyl-acid group), in detail.

\section{The gating-charge profile around $\mathbf{S} 4$ is critical}

The $G(V)$-shifting effect of Wu32 (Article I), DHAA (Article I) and Wu161 (Article II), followed an oscillatory pattern when the top gating charge was moved around the voltage sensor in $3 \mathrm{D}$ space, towards the extracellular side (Figure $3 \mathrm{C}-\mathrm{F}, \mathrm{H}$ in Article I; Figure 9 in Article II). Specifically, an arginine at positions 359 or 360, which faces the $\mathrm{S}_{3} / \mathrm{S}_{4}$ cleft in the final 'up-state', increased the resin acid-induced $G(V)$-shift (Figure 10, presumably because the resin acid keeps the voltage sensor rotated clockwise). On the other hand, an arginine on the opposite side of the $\mathrm{S}_{3} / \mathrm{S}_{4}$ cleft (positions 357, 361) decreased the resin acid-induced $G(V)$-shift (Figure 10, probably because the resin acid rotates the voltage sensor counter-clockwise). Overall, the effects of the resin acids were similar but, for one of the Shaker $\mathrm{K}_{\mathrm{V}}$ channel mutants there was a difference; both DHAA and Wu32 had twice as large an effect on the R362Q Shaker channel mutant, compared to Wu161 (Figure 9D in Article

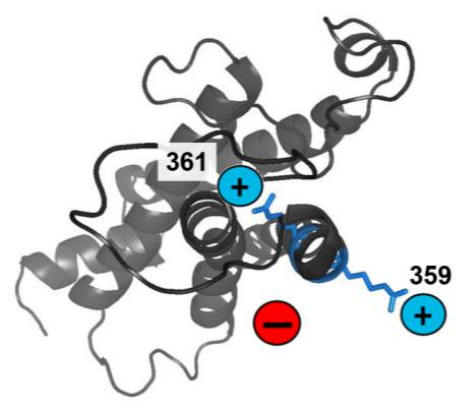

Figure 10. A359 and L361R on opposite sides of the S4 helix and the negative resin acid charge placed in the S3/S4 cleft. I), for as yet unknown reasons.

When the positively charged arginine was changed to a negatively charged glutamate at the most sensitive positions around the voltage sensor $(359,360,361)$ the Wu32induced $G(V)$-shift was reversed (e.g. a glutamate at position 359 reduced the Wu32induced $G(V)$-shift instead of increasing it) (Figure $3 \mathrm{G}$ in Article $I$ ), suggesting that the resin-acid induced rotation of the voltage sensor alters direction depending on the sign of the gating charge at the extracellular end of the voltage sensor. Together, the results suggest that there is an electrostatic interaction between the resin acid and the voltage sensor when the resin acids bind in the $\mathrm{S}_{3} / \mathrm{S}_{4}$ cleft. 


\section{The resin acid charge is crucial for the effect}

If there is an electrostatic interaction between the resin acid and the voltage sensor, the $G(V)$-shifting effect should also be sensitive to changes of the resin acid charge (= carboxyl group):

(i) The effect of resin acids, with a carboxyl group, is $\mathrm{pH}$ dependent (e.g. Figure 3A in Article I, Figure 4C in Article II). When most molecules are negatively charged, deprotonated at $\mathrm{pH} 10$, the $G(V)$-shifting effect is largest. Lowering the $\mathrm{pH}$, decreases the effect, until it is finally abolished (the functional $p \mathrm{~K}_{\mathrm{a}}$ value for DHAA is 7.2). This type of $\mathrm{pH}$ dependence has previously been reported for other DHAA derivatives (Ottosson et al, 2015), but it was unclear if the charge was needed for binding or if the charge electrostatically interacted with the voltage sensor.

(ii) The $G(V)$-shifting effects of resin acids can be increased at $\mathrm{pH} 7.4$, several fold, if the carboxyl group is replaced by a permanently negatively charged sulfonic-acid group (Figure 6 in Article II; Supplementary Figure 2, in Article I). Uncharged DHAA derivatives have on the other hand no effect (Figure 6 in Article II).

(iii) If the negatively charged carboxyl group is changed to a positively charged amine group, the compound shifts the $G(V)$-curve in the opposite direction, towards more positive voltages (Figure 3A,B in Article I). Clearly, this is supporting an electrostatic interaction between the resin acid and the voltage sensor.

Taken together, we now envision that the three-ringed motif of the resin acid molecule is important for anchoring of the compound in the lipid bilayer and that the charged group of the resin acid molecule is the actual effector, that electrostatically interacts with the voltage sensor, to either facilitate or hinder the voltage-sensor movement, depending on the sign of the charge (illustratively summarized in Figure 1A-B in Article II).

\section{Combining modifications of the DHAA molecule increase the effect (Aim 2)}

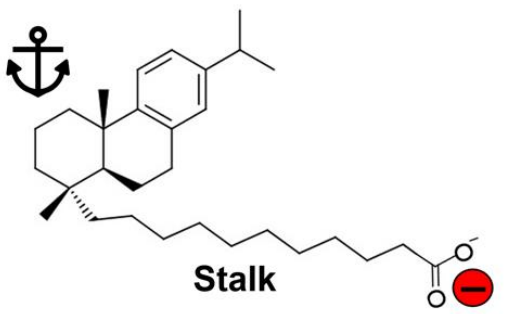

Figure 11. Nomenclature for different parts of the DHAA molecule.
To further characterize and explore the importance of the effector (=resin acid charge) we modified the effector's position, and valence of charge, alone or in combination with an efficient modification of the anchor (=hydrophobic three-ringed motif) (Figure 11). 


\section{A stalk between the anchor and effector}

A stalk with up to eleven atoms between the anchor and the effector (Figure 11) was introduced to alter the position of the effector, which was made fully charged (= all molecules are negatively charged) to minimize the environmental influence (e.g. deep inside the lipid bilayer or closer to the extracellular solution) on the functional $p \mathrm{~K}_{\mathrm{a}}$ value. For the WT Shaker $\mathrm{K}_{\mathrm{V}}$ channel we found that the $G(V)$-shifting effect increased when the stalk was prolonged from one to three atoms (Figure 4D in Article II). These results fit with a model, where the electrostatic interaction increases at longer stalks because the negative charge of the resin acid comes closer to the positive charges on the voltage sensor (Figure 12A). For the $3 \mathrm{R}$ Shaker $\mathrm{Kv}$ channel the effect was similar for stalk lengths between one and three atoms (Figure 4B in Article II), probably because the negative charge of the resin acid already is close enough to the positive charges on the voltage sensor, even at shorter stalk lengths (Figure 12B).

\section{A WT Shaker}

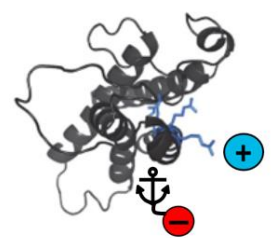

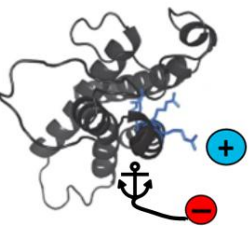

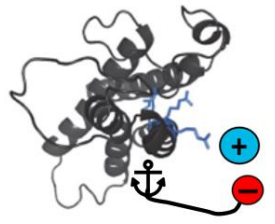

B 3R Shaker

Figure 12. A) A negative charge on a stalk, anchored between S3 and S4 come closer to the charge of the voltage sensor of the WT Shaker $\mathrm{K}_{v}$ channel, as the stalk length is extended B) A negative charge of the resin acid is close to the gating charges of the 3R Shaker Kv channel

For both channels, there was however a sudden cut-off in the effect for stalk lengths beyond three atoms (Figure 4B, D in Article II), as if the charge on the stalk suddenly found a position, far away for the channel. A simple electrostatic model that we made, suggests that when the stalk, anchored inside the membrane, is long enough to reach the outside of the lipid bilayer it will do so, because this is more energetically favourable for the charge attached to the stalk, than interacting with a charge of opposite sign inside the membrane (Figure 5 in Article II). The cut-off length for the stalk, in the model, is mainly sensitive to alterations of the anchoring depth inside the membrane. Thus, the stalk length is a powerful tool to be used in modulating the $G(V)$ shifting effect of resin acids and can potentially be even more so if a resin acid has a deeper binding-site inside the lipid bilayer.

\section{A divalent charge at the end of the stalk}

DHAA derivatives with a permanently charged effector (sulfonic-acid group), and an optimal stalk length of three atoms, shift the $G(V)$-curve of the $3 \mathrm{R}$ Shaker $\mathrm{Kv}$ channel, approximately $-30 \mathrm{mV}$ (Wu161 and Wu109, Figure 6 in Article II). It is therefore reasonable to think that the $G(V)$-shifting effect can be increased even more if two 
negative charges are put at the end of the stalk (because the electrostatic effect would increase if a divalent charge is placed in the same position as a monovalent charge). However, a resin acid with a divalent charge was found to be less efficient, compared to the compounds with one negative charge (Figure $7 \mathrm{~B}-\mathrm{C}$ in Article II). A possible explanation, suggested from our electrostatic model, can be that a stalk with a divalent charge favors a position closer to the water (further away from the charge in the membrane) even shorter stalks lengths, than for stalks with one negative charge (Figure 7A in Article II), but other explanations could be possible as well.

\section{Combination of an effective anchor, stalk and effector group}

The effect of DHAA can also be increased by modifying the anchor (Ottosson et al., 2015). Wu50 (Figure 13A) with a stronger anchor has a very similar $G(V)$-shifting effect to that of Wu161 (Figure 13A-B; Figure 10A,B in Article II) with a strong effector. When an effective anchor, stalk and effector group, were combined (Wu181, Figure 13A), the affinity was higher and the maximal effect on the $3 \mathrm{R}$ Shaker Kv channel was larger, than for any modification alone (Figure 13B). At lower concentrations the effect of Wu181 is increased by a factor of 32 (Figure 9 in Article II), compared to the mother compound DHAA. Thus, combining modifications of the anchor, and effector site is very powerful.

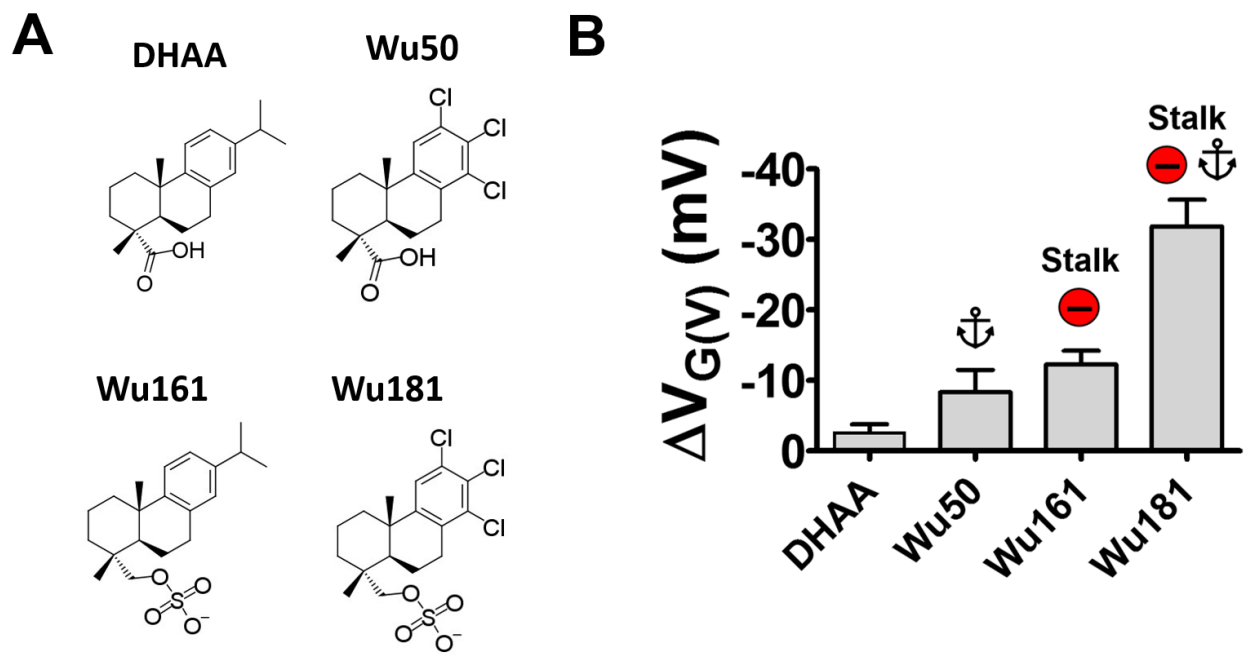

Figure 13. A) Molecular structure of DHAA, Wu50, Wu161, Wu181. B) Resin-acid induced G(V)-shift by $10 \mu \mathrm{M}$ compound at $\mathrm{pH} 7.4,3 \mathrm{R}$ Shaker $\mathrm{K}_{v}$ channel. Modification of the DHAA molecule illustrated as in Figure 11. 


\section{DHAA derivatives open the human M-type Kv7.2/7.3 channel (Aim 3)}

Resin acids open the Shaker $\mathrm{K}_{\mathrm{v}}$ channel, but do they have any effect on a human $\mathrm{K}_{\mathrm{V}}$ channel crucial for disease that can be used as a pharmaceutical target? This was a question that we set out to investigate in Article II when we tested the effect of several resin acids, on the the human M-type (hKv7.2/7.3) channel (Figure 11 in Article II). The $\mathrm{hKv} v .2 / 7.3$ channel is a non-inactivating $\mathrm{Kv}$ channel that has profound dampening effects on neuronal cellular excitability since it opens close to the resting-membrane potential. The channel has been used as a target for the 'first-in-class' anti-epileptic drug retigabine (Wuttke et al., 2005). Retigabine binds to the hKv7.2/7.3 channel from the intracellular side of the pore domain and stabilize the channel in the open state, so that the channel opens at more negative membrane voltages (Corbin-Leftwich et al., 2016). However, due to side effects (related to off-targets and/or metabolites) it was taken out of use (Garin Shkolnik et al., 2014; Stas et al., 2016; Tompson et al., 2016). In addition, both $\mathrm{Kv}_{7.2}$ and $\mathrm{K}_{v 7.3}$, have a similar charge profile around $\mathrm{S} 4$ to that of the Shaker $\mathrm{Kv}_{\mathrm{v}}$ channel, and it is known that the PUFA docosahexaenoic acid (DHA), that also acts via an electrostatic mechanism (Börjesson and Elinder, 2011), opens the hKv7.2/7.3 channel at low concentrations (Liin et al., 2016b).

Our DHAA derivatives opened the hKv7.2/7.3 channel (Figure 11 in Article II), by shifting the $G(V)$-curve in the negative direction along the voltage axis, as it does for the Shaker $\mathrm{KV}_{V}$ channel. The charge of the resin acid was crucial for the effect and a stalk length of three atoms, between the anchor and effector, was the optimal choice. Wu181, which has an effective anchor, stalk and effector, had the largest $G(V)$-shifting effect. $1 \mu \mathrm{M}$ Wu181 shifted the $G(V)$ curve of the hKv7.2/7.3 channel by $-4 \mathrm{mV}$, which is a shift that can reduce cellular excitability and be clinically relevant (Tigerholm et al., 2012).

\section{A resin acid affects cardiac excitability and several ion currents (Aim 4)}

The naturally occurring resin acid, isopimaric acid (IPA), that opens the Shaker $\mathrm{Kv}_{\mathrm{v}}$ channel (Ottosson et al., 2015), the BK channel (Imaizumi et al., 2002), and reduces the action potential frequency in neurons (Kobayashi et al., 2008; Wu et al., 2014), was used to explore the effect of a resin acid on cardiac excitability, and several cardiac ion currents.

\section{IPA reduces cardiac action-potential frequency}

IPA reduced the action-potential frequency of spontaneously beating cardiomyocytes (HL-1 cells) at lower concentrations (1-25 $\mu \mathrm{M}$ ), with up to $50 \%$, but had no effect at a higher concentration $(50 \mu \mathrm{M})$. The effect on other action-potential parameters, such as action-potential duration and amplitude, varied with concentrations, but was less pronounced than that for the frequency (Figure 1 in Article III). 


\section{IPA shifts the gating parameters of most ion currents}

To understand the underlying mechanism of the reduced action-potential frequency, we tested the effect of IPA on several ion currents; the $\mathrm{Na}^{+}$current $\left(I_{\mathrm{Na}}\right)$, the L-type $\mathrm{Ca}^{2+}$ current ( $\mathrm{I}_{\mathrm{CaL}}$ ), the T-type $\mathrm{Ca}^{2+}$ current ( $\mathrm{I}_{\mathrm{CaT}}$ ), the funny current $\left(\mathrm{I}_{\mathrm{f}}\right.$ ), rapid delayed rectifier $\mathrm{K}^{+}$current $\left(\mathrm{I}_{\mathrm{Kr}}\right)$ and the transient outward current $\left(\mathrm{I}_{\mathrm{to}}\right)$.

IPA shifted the gating parameters for most ion currents in the negative direction along the voltage axis, but there were clear differences between the different types of ion currents, as summarized in Table 1.

\begin{tabular}{|c|c|ccccccc|}
\multicolumn{4}{c}{ Amplitude } & \multicolumn{3}{c}{ G(V)-shift } & \multicolumn{3}{c|}{ Inactivation shift } \\
\hline$[\mathrm{IPA}]$ & $10 \mu \mathrm{M}$ & $1 \mu \mathrm{M}$ & $10 \mu \mathrm{M}$ & $50 \mu \mathrm{M}$ & $1 \mu \mathrm{M}$ & $10 \mu \mathrm{M}$ & $50 \mu \mathrm{M}$ \\
\hline $\mathrm{I}_{\mathrm{Na}}$ & $\rightarrow$ & -4.4 & -6.1 & -5.2 & -5.8 & -9.0 & -12.8 \\
$\mathrm{I}_{\mathrm{CaL}}$ & $\downarrow$ & -6.6 & -7.3 & -7.6 & -10.8 & -13.2 & -10.7 \\
$\mathrm{I}_{\mathrm{CaT}}$ & $\downarrow$ & -3.3 & -4.7 & -7.3 & -5.2 & -11.6 & -16.5 \\
$\mathrm{I}_{\mathrm{f}}$ & $\rightarrow$ & -0.3 & -1.1 & -3.7 & & & \\
& & & & & & & \\
$\mathrm{I}_{\mathrm{to}}$ & $\uparrow$ & 0.5 & -1.3 & -0.4 & -2.7 & -5.1 & -9.4 \\
$\mathrm{I}_{\mathrm{Kr}}$ & $\rightarrow$ & -6.0 & -5.4 & -8.3 & 0.3 & -2.4 & -3.8
\end{tabular}

Table 1. Effect of IPA on six different ion currents at 1, 10 and $50 \mu \mathrm{M}$. The shifts are colour coded as following; white $<5 \mathrm{mV}$, blue $5-10 \mathrm{mV}$, and yellow $>10 \mathrm{mV}$.

For $\mathrm{INa}_{\mathrm{Na}} \mathrm{I}_{\mathrm{CaL}}$ and $\mathrm{I}_{\mathrm{CaT}}$, that initiate or maintain the action potential, the $G(V)$ curve and steady-state inactivation curve was shifted in a negative direction along the voltage axis (Figure 2, 5 and 6 in Article III). The effect was larger for inactivation than for $G(V)$ (Table 1). In addition, the amplitudes of $\mathrm{I}_{\mathrm{CaL}}$ and $\mathrm{I}_{\mathrm{CaT}}$ were decreased (Table 1; Figure 5 and 6 in Article III), which would counteract the $G(V)$ shift towards more negative membrane potentials. IPA had no effect on the If current (Figure 7 in Article III), which otherwise is known to be important for the rhythmicity of heart, and when the effect was tested on two different $\mathrm{K}^{+}$currents, various effects were seen. For $\mathrm{I}_{\mathrm{Kr}}$, the $\operatorname{Gr}(V)$-curve was shifted in a negative direction along the voltage axis, while the steady-state inactivation curve was not affected (Figure 4 in Article III). For Ito the maximum conductance increased (despite that the $G_{t o}(V)$-curve was not shifted), and the steady-state inactivation was shifted in negative direction along the voltage axis (Figure 3 in Article III). Altogether, the effects on the ion currents suggest a reduction of action potential frequency.

\section{Computer simulations}

To better understand if the effect on the different ion currents can explain the reduced action-potential frequency at lower concentrations, and the lack thereof at a higher concentration, the gating parameters seen experimentally were implemented in a 
computer model of a spontaneously beating Purkinje fiber cell (in the absence of functional HL-1 cell model). First, the gating parameters were implemented channel by channel and thereafter all gating parameters together. Most significantly, altering the gating parameters of $\mathrm{I}_{\mathrm{Na}}$, reduced firing frequency at lower concentrations, while the reduction at the highest concentration was smaller (Figure 8 in Article III). When all gating parameters were implemented simultaneously the reduction was larger than for any of the individual channels alone.

\section{IPA reverses arrhythmic firing of cardiomyocytes}

Incubation of HL-1 cells with isoproterenol overnight induced highly irregular actionpotential firing (Figure 14). The rhythmicity was partially or fully restored by 1 and 10 $\mu \mathrm{M}$ IPA (Figure 14; Figure 9 in Article III), respectively.

Induced arrhythmia

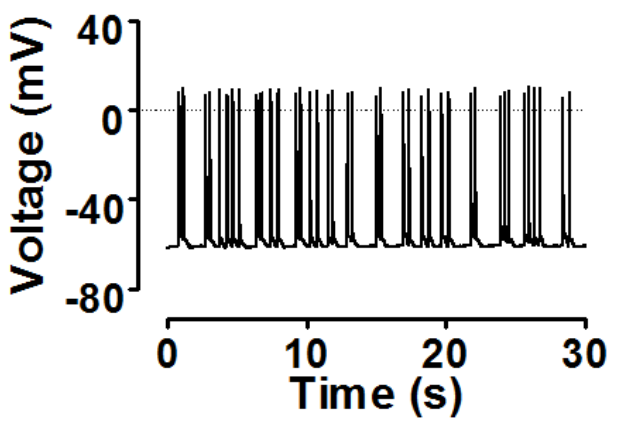

$10 \mu \mathrm{M}$ IPA

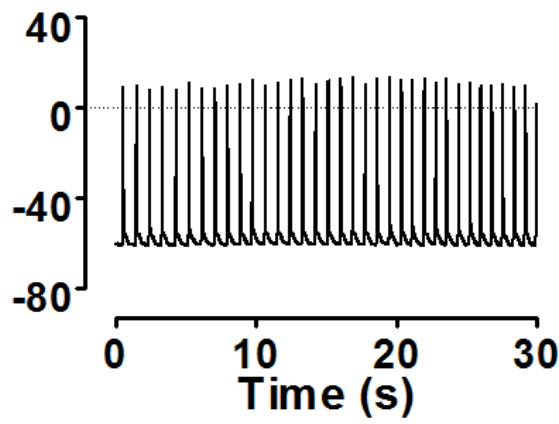

Figure 14. Induced arrhythmia in $\mathrm{HL}-1$ cells with $10 \mu \mathrm{M}$ Isoproterenol overnight (left), which could be reversed by $10 \mu \mathrm{M}$ IPA (right).

Taken together, the naturally occurring resin acid, IPA, is new type of a small-molecule compound that affects cardiac excitability. Potentially, resin acids can be developed into new compounds to be used against cardiac arrhythmias such as atrial fibrillation, and the promiscuous effect on several ion currents could be a beneficial strategy in the development. 


\section{DISCUSSION}

In Article I we describe that resin acids bind between the lipid bilayer and the Shaker $\mathrm{K}_{\mathrm{v}}$ channel, in a pocket in the $\mathrm{S}_{3} / \mathrm{S}_{4}$ cleft of the VSD, on the extracellular side of the membrane. Usually, small-molecule compounds interact with ion channels from pockets surrounded by water, making this lipid-exposed pocket a fundamentally new interaction site for small-molecule compounds. Furthermore, we showed that resin acids open the Shaker $\mathrm{K}_{\mathrm{v}}$ channel via an electrostatic mechanism of action, exerted on the positively charged voltage sensor, and that the $G(V)$-shifting effect of a resin acids could be increased by:

(i) Using a permanently negatively charged effector

(ii) Introducing a stalk with up to three atoms between the anchor and the effector

(iii) Combining $i$ and ii with modifications of the anchor

DHAA derivatives, with these modifications, opened the human M-type ( $\mathrm{hK} v$ 7.2/7.3) channel, which has profound dampening effect on cellular excitability of neurons. A naturally occurring resin acid also reduced the excitability of cardiomyocytes, by shifting the gating-parameters of several cardiac ion currents. Accordingly, there are both challenges and opportunities for developing resin acids into pharmaceutical compounds that modulate the excitability of excitable cells, which will be highlighted in the discussion below.

\section{Comparison with other agents that affect ion-channel gating}

The modulation of voltage-gated ion channels by different compounds, ions, toxins and lipids, is diverse in terms of binding site and mechanisms (Cestèle and Catterall, 2000; Elinder and Arhem, 2003; Liin et al., 2016b; Wulff et al., 2009). Metal ions affect the gating of voltage-gated ion channels, both electrostatically (e.g. changing surface charge density) and non-electrostatically (e.g. binding to the channel), and indirectly from sites close to the channel, or directly by binding to the channel (Elinder and Arhem, 2003). Toxins also have several binding sites to voltage-gated ion channels, such as the pore domain, and the $\mathrm{S}_{3}-\mathrm{S} 4$ linker (voltage-sensor trapping toxins) (Cestèle and Catterall, 2000). In common with resin acids, the extracellular parts of $\mathrm{S}_{3}$ and $\mathrm{S}_{4}$ of the $\mathrm{K}_{\mathrm{v}} 3.1$ channel contribute to the sensitivity of the toxin gamberiol, presumably by modulating the accessibility to the binding pocket between the VSD and the pore domain, from which gamberiol stabilizes the $\mathrm{K}_{\mathrm{v} 3.1}$ channel in the closed state (Kopljar et al., 2016). Small-molecule compounds have also been developed to open or close $\mathrm{Kv}_{v}$ channels (Wulff et al., 2009). With respect to Kv channel openers, the industry has primarily focused on developing compounds that activate the M-current, thus targeting Kv7.1-7.5 channels, as was done with the Kv7 channel opener and anti-epileptic drug retigabine, but other compounds are also known to open Kv7 channels, such as zinc pyrithione, ICA-27243, diclofenac or Maxipost (BMS204352). However, none of these compounds have the same binding site to the $\mathrm{KV}_{\mathrm{V}}$ 
channels as the resin acids. Instead, resin acids share several characteristics with PUFAs. Structurally, both require a hydrophobic part (tail or three-ringed motif) for anchoring in the lipid bilayer, and a charged group to shift the $G(V)$ curve of $\mathrm{KV}_{\mathrm{V}}$ channels, towards more negative membrane voltages (negative charge) or positive membrane voltages (positive charge). The binding sites around the voltage sensor to $\mathrm{Kv}$ channels also overlap to some extent with each other (Liin et al., 2015; Yazdi et al., 2016). This explains why the amplitude of the $G(V)$-shifting effect, for both resin acids (Article I and II) and PUFAs (Ottosson et al., 2014), follows a similar oscillatory pattern when the positive gating charge, at the top of voltage sensor S4, is moved around in $3 \mathrm{D}$ space. In addition PUFAs act on many types of voltage-gated ion channels, from at least five different binding sites to alter the maximal conductance, kinetics and voltage dependence for various types of ion channels (Elinder and Liin, 2017). More specifically, PUFAs shifts the inactivation of Nav and Cav channels, and the $G(V)$ of non-inactivating $\mathrm{Kv}$ channels towards more negative membrane potentials. This is in line with what we found for the naturally occurring resin acid, IPA (Article III) when we tested the effects on several ion currents in cardiomyocytes. This suggests that resin acids and PUFAs act via a similar mechanism on several voltage-gated ion channels.

\section{The effect on several voltage-gated ion channels}

A variety of resin acids, and derivatives of resin acids, reduce cellular excitability in sensory neurons (Ottosson et al., 2015), prevent hyper-excitability in auditory cortical networks (Wu et al., 2014) and moderately inhibit epileptic activity in hippocampal neurons (Kobayashi et al., 2008). In my thesis work, we show that IPA also reduces the action-potential frequency of cardiomyocytes by acting on several voltage-gated ion channels. For Nav channels and Cav channels the top gating charge, in the extracellular end of the voltage sensor, is located further out (extracellular side), of motif IV and II, respectively, compared to the other motifs. As described in the introduction, these VSDs are important for the fast inactivation, suggesting that the quantitative differences for the inactivation versus $G(V)$ effects, seen for both PUFAs and resin acids on Nav and Cav channels, likely reflect the variation of the gatingcharge distribution around the voltage sensor. However, even for channels that have a similar charge profile at the top of the voltage sensor, quantitative differences are seen. For example, both PUFAs (Liin et al., 2016b) and resin acids (Article II) have a larger $G(V)$-shifting effect on the human M-type (hKv 7.2/7.3) channel than on the Shaker $\mathrm{Kv}$ channel. Thus, suggesting that the affinity to the VSD and/or the closeness between the effector and gating charges also plays a role.

Hence, if PUFAs and a naturally occurring resin acid interact with several types of voltage-gated ion channels, and in the case of PUFAs also have several binding sites to different ion channels, is it possible that modifications of resin acids could be used to increase the selectively between different voltage-gated ion channels, from the binding site in the $\mathrm{S}_{3} / \mathrm{S}_{4}$ cleft of the VSD? 


\section{Combining modifications of a resin acid - a powerful possibility}

Both DHAA and Wu32 have twice as large effect on the Shaker S4 mutant R362Q than the PUFA DHA, but the difference disappears when a stalk is put between the anchor and the effector of DHAA (Wu161, Figure 6 in Article II). A stalk is a powerful tool for increasing the effect of DHAA derivatives on the WT Shaker $\mathrm{K}_{V}$ channel, and on the human M-type ( $\mathrm{hKv}_{v}$ 7.2/7.3) channel (Article II). In addition, Wu32 and some other DHAA derivatives with modifications of the anchor (e.g. methyloxime at $\mathrm{C}_{7}$ on the Bring), appear to have a deeper and/or tighter binding site to the Shaker Kv channel, with a larger effect on closing kinetics than expected, than if they only acted on the voltage sensor via electrostatic interactions (Elinder and Arhem, 2003). We also show in Article II that minor modifications of the DHAA molecule, such as changing the chirality of the carboxyl group, can have a profound effect for the $G(V)$-shifting effect of a resin acid (Wu et al., 2018). Thus, only small changes of the resin acid molecule (anchor, stalk and effector) can be very powerful; each in combination with the others make it possible both to fine tune the binding of the resin acid to different channels, and/or increase or decrease the electrostatic interaction depending on the gatingcharge profile around the voltage sensor. Combinatorial modifications, of the anchor, stalk and effector were indeed powerful in increasing the resin-acid induced effect on the human M-type (hKv7.2/7.3) channel. This leaves us with some exciting modification puzzles to be examined in the future.

In conclusion, resin acids are potential drug candidates for diseases such as epilepsy and cardiac arrhythmia. Knowing the binding site and mechanism of action can help to fine tune the resin acid to increase their effect, and possibly also the ion channel selectivity in the future. 


\section{ACKNOWLEDGEMENTS}

This thesis would not have been possible without the help and support from many of you. I would like to thank:

Professor Fredrik Elinder, my supervisor, it was eight years ago since I sent you the first email (as a master student) and I have felt your support since day one! Your ability to pin down complex research questions to one simple question, the hours you put into research, and the knowledge you have about everything: inspiring, remarkable and impressive. You always give good advises that you can learn from!

Johan Brask, my co-supervisor, you know everything about noise, glues (go Mora!), cell-culturing, and all other practical skills you need to know when doing electrophysiology, it is impressive! Thank you for being a good office mate that always ask how it is the first thing you do.

To the past and present members of the Elinder Group: Nina Ottosson, for the wonderful collaboration with the resin acids, for your inspiring ability to see things as an entrepreneur, and for being a good listener and travelling mate. Urban Karlsson, your calmness in combination with your knowledge about electrophysiology and everything else is impressive. Jakob Renhorn, thank you for answering all questions about the oocytes and for your driving skills in L.A. Andreas Nolting, it is always fun discussing ion channels with you, in particular the Mchannel. Olle Rönnelid, it is fun sharing tips and trix with someone that also like ion channels. Sajjad Salari, for the collaboration with the cardiomyocytes and for sitting with me as I learned the patch-clamp technique cell after cell. Ulrika Englund, my lab mate during the evenings, you are missed, and thank you for teaching me how to do frog surgery the left-hand way. Luca Conit, for your knowledge about ion channels and for showing me what a wonderful place Rome is. Per-Erik Lund for keeping me busy with molecules.

Group Liin: Sara Linn, you impress me with your knowledge, your invaluable feedback, the way you get things done in the lab, and that you like A.I as well. Johan Larsson, not only do you know much about ion channels but also humans and it was a good idea to go to a basketball game to get some shoes.

To the collaborators that made these projects possible: Xiongyu Wu and Peter Konradsson, for the synthesis and purification of all the resin acids derivatives. Wusse, you are incredible, even the most difficult molecules (and requests) does not stop you for trying. Samira Yazdi and Erik Lindahl, for all the help with molecular docking and molecular dynamics simulations. Peter Münger and Ingemar Lundström, for enthusiastically calculating electrostatic interactions, I very much enjoyed our discussions.

Past and present members of floor 11: Björn, Sofie (for liking licorice and leaving some for me), Gonzalo, Sarah, Erik J, Anders F, Pierre, Batu, Sonal, Eli, David, Anna K, Michael, Elahe, Anna N, Maarit, Daniel, Anders B, Kiseko, Anna E, Filip, Johan, Ana-Maria, Takashi, Simin, Ayman, Alison. You have made floor 11 a wonderful workplace and thank you for attending the ElectroJC. 
Eric Glowaki and Marie Jakesova for challenging me with a new exciting project.

The staff at the animal facility for taking care about the frogs, Larry for proof reading the thesis and everyone proof reading the manuscripts, Anna and Camilla at the administration for all help and your good mood, the staff at the core facility for all ion channel sequencing. The students in the lab that have worked on various projects with me.

\section{With all love that cannot be expressed in enough words}

Anna Södergren, I consider you, Stefan and A, as my second family. You are, and have been, an incredible friend during all these years in Linköping. Without you I would still wandering around at Valla looking for my bicycle or my keys. Your friendship is invaluable for me. Johanna Billqvist, thank you for being my friend, classmate (who shared my love for mornings), and for listening to all my thoughts about what to do/not to do, and being there during all fun times as well. Sara Sjölund, not just our friendship (!), I will always be grateful for all walks we took that summer. Malin S, Malle, Jennie, Therese L, Malin M, Angelica, Lollo, Mia, thank you for letting me be me, and for your endless support and incredible friendship spanning over decades. Sofia K, Jessica, Sofia L, Mattias, Jonas, Minna, Eddie, Erik $\mathbf{K}$ without you the time in Linköping would not have been the same (or the following 10 years after that). For you that made the master and $\mathrm{PhD}$ studies fun, Erin, Dimitri, Stefan, Emina, Cynthia, Kjersti, Liam, Erik (for taking me out on parties when needed). Filip, for your friendship, teaching skills, and news. Samuel, I have kept your picture in mind when reading articles. For all not mentioned but not forgotten $<3$

\section{Min familj}

Mamma du har alltid fått mig att känna att det är okej att gå sin egen väg och alltid stöttat mig vad det än det är. Jag vet var jag har fătt min envishet ifrån: upp och ner från hästar, och från dig. Danne för att du är världens bästa bror, som alltid har ett filmtips när man behöver det, som glatt gjorde framsidan, och för att du alltid finns där. Mormor jag vet att du kommer vara lyckligast över detta, tack för all kärlek. Moster, Peter, Frida, Emil jag vet att ni alltid finns där vad som än händer, även när håret blir blått. Clabbe för all hjälp med allt (som bokhyllor som faktiskt håller för böcker) och kanske överlever vi en biltur. Sara, Kerstin, Mina, Ronja för ni gör familjen lite större och alltid är så snälla.

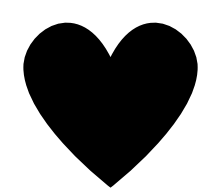




\section{REFERENCES}

Agnew, W.S., Levinson, S.R., Brabson, J.S., and Raftery, M.A. (1978). Purification of the tetrodotoxin-binding component associated with the voltage-sensitive sodium channel from Electrophorus electricus electroplax membranes. Proc. Natl. Acad. Sci. U. S. A. 75, 2606-2610.

An, M.T., and Zamponi, G.W. (2013). Voltage-dependent inactivation of voltage gated calcium channels (Landes Bioscience).

Armstrong, C.M. (1969). Inactivation of the potassium conductance and related phenomena caused by quaternary ammonium ion injection in squid axons. J. Gen. Physiol. 54, 553-575.

Armstrong, C.M., and Bezanilla, F. (1974). Charge movement associated with the opening and closing of the activation gates of the Na channels. J. Gen. Physiol. 63, 533-552.

Armstrong, C.M., and Bezanilla, F. (1977). Inactivation of the sodium channel. II. Gating current experiments. J. Gen. Physiol. 70, 567-590.

Armstrong, C.M., and Hollingworth, S. (2017). A perspective on $\mathrm{Na}$ and $\mathrm{K}$ channel inactivation. J. Gen. Physiol. jgp.201711835.

Armstrong, C.M., Bezanilla, F., and Rojas, E. (1973). Destruction of sodium conductance inactivation in squid axons perfused with pronase. J. Gen. Physiol. 62, 375-391.

Bagal, S.K., Marron, B.E., Owen, R.M., Storer, R.I., and Swain, N.A. (2015). Voltage gated sodium channels as drug discovery targets. Channels 9, 360-366.

Bartos, D.C., Grandi, E., and Ripplinger, C.M. (2015). Ion Channels in the Heart. Compr. Physiol. 5, 1423-1464.

Beeler, G.W., and Reuter, H. (1970). Membrane calcium current in ventricular myocardial fibres. J. Physiol. 207, 191-209.

Bernstein, J. (1902). Untersuchungen zur thermodynamik der bioelektrischen ströme. Erster Tail. Pflügers Arch. Bd 92, 521-562.

Bezanilla, F., and Armstrong, C.M. (1977). Inactivation of the sodium channel. I. Sodium current experiments. J. Gen. Physiol. 70, 549-566.

Biel, M., Wahl-Schott, C., Michalakis, S., and Zong, X. (2009). Hyperpolarization-Activated Cation Channels: From Genes to Function. Physiol. Rev. 89, 847-885.

Birnbaum, S.G., Varga, A.W., Yuan, L.-L., Anderson, A.E., Sweatt, J.D., and Schrader, L.A. (2004). Structure and function of Kv4-family transient potassium channels. Physiol. Rev. 84, $803-833$.

Börjesson, S.I., and Elinder, F. (2008). Structure, function, and modification of the voltage sensor in voltage-gated ion channels. Cell Biochem. Biophys. 52, 149-174.

Börjesson, S.I., and Elinder, F. (2011). An electrostatic potassium channel opener targeting the final voltage sensor transition. J. Gen. Physiol. 137, 563-577.

Börjesson, S.I., Hammarström, S., and Elinder, F. (2008). Lipoelectric modification of ion channel voltage gating by polyunsaturated fatty acids. Biophys. J. 95, 2242-2253. 
Börjesson, S.I., Parkkari, T., Hammarström, S., and Elinder, F. (2010). Electrostatic Tuning of Cellular Excitability. Biophys. J. 98, 396-403.

Brodie, M.J. (2010). Antiepileptic drug therapy the story so far. Seizure 19, 650-655.

Brodie, M.J. (2017a). Sodium Channel Blockers in the Treatment of Epilepsy. CNS Drugs 31, 527-534.

Brodie, M.J. (2017b). Tolerability and Safety of Commonly Used Antiepileptic Drugs in Adolescents and Adults: A Clinician's Overview. CNS Drugs 31, 135-147.

Brown, D.A., and Adams, P.R. (1980). Muscarinic suppression of a novel voltage-sensitive K+ current in a vertebrate neurone. Nature $283,673-676$.

Campiglio, M., and Flucher, B.E. (2015). The Role of Auxiliary Subunits for the Functional Diversity of Voltage-Gated Calcium Channels. J. Cell. Physiol. 230, 2019-2031.

Catterall, W.A. (2000). From ionic currents to molecular mechanisms: The structure and function of voltage-gated sodium channels. Neuron 26, 13-25.

Catterall, W.A. (2011). Voltage-Gated Calcium Channels. Cold Spring Harb. Perspect. Biol. 3.

Catterall, W.A., and Swanson, T.M. (2015). Structural Basis for Pharmacology of VoltageGated Sodium and Calcium Channels. Mol. Pharmacol. 88, 141-150.

Catterall, W.A., Schmidt, J.W., Messner, D.J., and Feller, D.J. (1986). Structure and biosynthesis of neuronal sodium channels. Ann. N. Y. Acad. Sci. 479, 186-203.

Catterall, W.A., Wisedchaisri, G., and Zheng, N. (2017). The chemical basis for electrical signaling. Nat. Chem. Biol. 13, 455-463.

Cestèle, S., and Catterall, W.A. (2000). Molecular mechanisms of neurotoxin action on voltage-gated sodium channels. Biochimie $82,883-892$.

Chanda, B., and Bezanilla, F. (2002). Tracking voltage-dependent conformational changes in skeletal muscle sodium channel during activation. J. Gen. Physiol. 120, 629-645.

Chen, L.Q., Santarelli, V., Horn, R., and Kallen, R.G. (1996). A unique role for the S4 segment of domain 4 in the inactivation of sodium channels. J. Gen. Physiol. 108, 549-556.

Choi, K.L., Aldrich, R.W., and Yellen, G. (1991). Tetraethylammonium blockade distinguishes two inactivation mechanisms in voltage-activated $\mathrm{K}+$ channels. Proc. Natl. Acad. Sci. U. S. A. $88,5092-5095$.

Claycomb, W.C., Lanson, N.A., Stallworth, B.S., Egeland, D.B., Delcarpio, J.B., Bahinski, A., and Izzo, N.J. (1998). HL-1 cells: A cardiac muscle cell line that contracts and retains phenotypic characteristics of the adult cardiomyocyte. Proc. Natl. Acad. Sci. 95, 2979-2984.

Conti, L., Renhorn, J., Gabrielsson, A., Turesson, F., Liin, S.I., Lindahl, E., and Elinder, F. (2016). Reciprocal voltage sensor-to-pore coupling leads to potassium channel C-type inactivation. Sci. Rep. 6, 27562.

Coraboeuf, E., and Weidmann, S. (1949). Potentiel de repos et potentiels d'action du muscle cardiaque, mesurés à l'aide d'électrodes intracellulaires. CR. Soc. Biol. 143, 1329-1331. 
Corbin-Leftwich, A., Mossadeq, S.M., Ha, J., Ruchala, I., Le, A.H.N., and Villalba-Galea, C.A. (2016). Retigabine holds $\mathrm{KV}_{7}$ channels open and stabilizes the resting potential. J. Gen. Physiol. 147, 229-241.

Cui, Y.-M., Yasutomi, E., Otani, Y., Yoshinaga, T., Ido, K., Sawada, K., Kawahata, M., Yamaguchi, K., and Ohwada, T. (2008). Novel oxime and oxime ether derivatives of 12,14dichlorodehydroabietic acid: design, synthesis, and BK channel-opening activity. Bioorg. Med. Chem. Lett. 18, 6386-6389.

Cui, Y.-M., Yasutomi, E., Otani, Y., Ido, K., Yoshinaga, T., Sawada, K., and Ohwada, T. (2010). Design, synthesis, and characterization of BK channel openers based on oximation of abietane diterpene derivatives. Bioorg. Med. Chem. 18, 8642-8659.

Cui, Y.-M., Liu, X.-L., Zhang, W.-M., Lin, H.-X., Ohwada, T., Ido, K., and Sawada, K. (2016). The synthesis and BK channel-opening activity of $\mathrm{N}$-acylaminoalkyloxime derivatives of dehydroabietic acid. Bioorg. Med. Chem. Lett. 26, 283-287.

Danielsson, C., Brask, J., Sköld, A.-C., Genead, R., Andersson, A., Andersson, U., Stockling, K., Pehrson, R., Grinnemo, K.-H., Salari, S., et al. (2013). Exploration of human, rat, and rabbit embryonic cardiomyocytes suggests K-channel block as a common teratogenic mechanism. Cardiovasc. Res. 97, 23-32.

Du Bois-Reymond, E. (1849). Untersuchungen über thierische elektrizität. (G. Reimer).

Elinder, F., and Arhem, P. (2003). Metal ion effects on ion channel gating. Q. Rev. Biophys. $36,373-427$.

Elinder, F., and Liin, S.I. (2017). Actions and mechanisms of polyunsaturated fatty acids on voltage-gated ion channels. Front. Physiol. 8.

Elinder, F., Männikkö, R., Pandey, S., and Larsson, H.P. (2006). Mode shifts in the voltage gating of the mouse and human HCN2 and HCN4 channels. J. Physiol. 575, 417-431.

Fozzard, H.A., Sheets, M.F., and Hanck, D.A. (2011). The Sodium Channel as a Target for Local Anesthetic Drugs. Front. Pharmacol. 2.

Galvani, L. (1791). De viribus electricitatis in motu musculari commentarius. Bon. Sci. Art. Inst. Acad. Comm. 7, 363-418.

Garin Shkolnik, T., Feuerman, H., Didkovsky, E., Kaplan, I., Bergman, R., Pavlovsky, L., and Hodak, E. (2014). Blue-gray mucocutaneous discoloration: a new adverse effect of ezogabine. JAMA Dermatol. 150, 984-989.

Gessner, G., Cui, Y.-M., Otani, Y., Ohwada, T., Soom, M., Hoshi, T., and Heinemann, S.H. (2012). Molecular mechanism of pharmacological activation of BK channels. Proc. Natl. Acad. Sci. U. S. A. 109, 3552-3557.

Goldin, A.L. (2006). Expression of Ion Channels in Xenopus Oocytes. In Expression and Analysis of Recombinant Ion Channels, J.J. Clare, and D.J. Trezise, eds. (Wiley-VCH Verlag GmbH \& Co. KGaA), pp. 1-25.

Gurdon, J.B., Lane, C.D., Woodland, H.R., and Marbaix, G. (1971). Use of Frog Eggs and Oocytes for the Study of Messenger RNA and its Translation in Living Cells. Nature 233, 177182. 
Hamill, O.P., Marty, A., Neher, E., Sakmann, B., and Sigworth, F.J. (1981). Improved patchclamp techniques for high-resolution current recording from cells and cell-free membrane patches. Pflugers Arch. 391, 85-100.

Henrion, U., Renhorn, J., Börjesson, S.I., Nelson, E.M., Schwaiger, C.S., Bjelkmar, P., Wallner, B., Lindahl, E., and Elinder, F. (2012). Tracking a complete voltage-sensor cycle with metalion bridges. Proc. Natl. Acad. Sci. U. S. A. 109, 8552-8557.

Hille, B. (2001). Ion channels of excitable membranes (Sunderland, MA: Sinauer Associates Inc).

Hodgkin, A.L., and Huxley, A.F. (1952a). Currents carried by sodium and potassium ions through the membrane of the giant axon of Loligo. J. Physiol. 116, 449-472.

Hodgkin, A.L., and Huxley, A.F. (1952b). The components of membrane conductance in the giant axon of Loligo. J. Physiol. 116, 473-496.

Hodgkin, A.L., and Huxley, A.F. (1952c). The dual effect of membrane potential on sodium conductance in the giant axon of Loligo. J. Physiol. 116, 497-506.

Hodgkin, A.L., and Huxley, A.F. (1952d). A quantitative description of membrane current and its application to conduction and excitation in nerve. J. Physiol. 117, 500-544.

Hodgkin, A.L., and Katz, B. (1949). The effect of sodium ions on the electrical activity of the giant axon of the squid. J. Physiol. 108, 37-77.

Hodgkin, A.L., Huxley, A.F., and Katz, B. (1952). Measurement of current-voltage relations in the membrane of the giant axon of Loligo. J. Physiol. 116, 424-448.

Hoshi, T., and Armstrong, C.M. (2013). C-type inactivation of voltage-gated K+ channels: pore constriction or dilation? J. Gen. Physiol. 141, 151-160.

Hoshi, T., Zagotta, W.N., and Aldrich, R.W. (1990). Biophysical and molecular mechanisms of Shaker potassium channel inactivation. Science 25O, 533-538.

Hoshi, T., Zagotta, W.N., and Aldrich, R.W. (1991). Two types of inactivation in Shaker K+ channels: effects of alterations in the carboxy-terminal region. Neuron $7,547-556$.

Humphries, E.S.A., and Dart, C. (2015). Neuronal and Cardiovascular Potassium Channels as Therapeutic Drug Targets Promise and Pitfalls. J. Biomol. Screen. 2O, 1055-1073.

Hutter, O.F., and Trautwein, W. (1956). Vagal and sympathetic effects on the pacemaker fibers in the sinus venosus of the heart. J. Gen. Physiol. 39, 715-733.

Imaizumi, Y., Sakamoto, K., Yamada, A., Hotta, A., Ohya, S., Muraki, K., Uchiyama, M., and Ohwada, T. (2002). Molecular Basis of Pimarane Compounds as Novel Activators of LargeConductance Ca2+-Activated K+ Channel a-Subunit. Mol. Pharmacol. 62, 836-846.

Isom, L.L., De Jongh, K.S., Patton, D.E., Reber, B.F., Offord, J., Charbonneau, H., Walsh, K., Goldin, A.L., and Catterall, W.A. (1992). Primary structure and functional expression of the beta 1 subunit of the rat brain sodium channel. Science 256, 839-842.

Isom, L.L., Ragsdale, D.S., De Jongh, K.S., Westenbroek, R.E., Reber, B.F., Scheuer, T., and Catterall, W.A. (1995). Structure and function of the beta 2 subunit of brain sodium channels, a transmembrane glycoprotein with a CAM motif. Cell 83, 433-442. 
Kamb, A., Iverson, L.E., and Tanouye, M.A. (1987). Molecular characterization of Shaker, a Drosophila gene that encodes a potassium channel. Cell 5O, 405-413.

Kaplan, W.D., and Trout, W.E. (1969). The behavior of four neurological mutants of Drosophila. Genetics 61, 399-409.

Karagueuzian, H.S., Pezhouman, A., Angelini, M., and Olcese, R. (2017). Enhanced Late Na and Ca Currents as Effective Antiarrhythmic Drug Targets. Front. Pharmacol. 8, 36.

Katz, A.M., and Repke, D.I. (1966). Control of myocardial contraction: the sensitivity of cardiac actomyosin to calcium ion. Science 152, 1242-1243.

Keynes, R.D., and Elinder, F. (1998). Modelling the activation, opening, inactivation and reopening of the voltage-gated sodium channel. Proc. Biol. Sci. 265, 263-270.

Keynes, R.D., and Elinder, F. (1999). The screw-helical voltage gating of ion channels. Proc. Biol. Sci. 266, 843-852.

Keynes, R.D., and Rojas, E. (1974). Kinetics and steady-state properties of the charged system controlling sodium conductance in the squid giant axon. J. Physiol. 239, 393-434.

Kobayashi, K., Nishizawa, Y., Sawada, K., Ogura, H., and Miyabe, M. (2008). K(+)-channel openers suppress epileptiform activities induced by 4-aminopyridine in cultured rat hippocampal neurons. J. Pharmacol. Sci. 108, 517-528.

Kölliker, R.A. von, and Müller, H. (1856). Nachweis der negativen schwankung des muskelstroms am natürlich sich contrahirenden muskel. Verh. Phys-med. Ges. Wiürzburg, 6, 528-533.

Kopljar, I., Grottesi, A., de Block, T., Rainier, J.D., Tytgat, J., Labro, A.J., and Snyders, D.J. (2016). Voltage-sensor conformation shapes the intra-membrane drug binding site that determines gambierol affinity in Kv channels. Neuropharmacology 107, 160-167.

Labro, A.J., Lacroix, J.J., Villalba-Galea, C.A., Snyders, D.J., and Bezanilla, F. (2012). Molecular mechanism for depolarization-induced modulation of $\mathrm{Kv}$ channel closure. J. Gen. Physiol. 140, 481-493.

Lecar, H., Larsson, H.P., and Grabe, M. (2003). Electrostatic model of S4 motion in voltagegated ion channels. Biophys. J. 85, 2854-2864.

Ledwell, J.L., and Aldrich, R.W. (1999). Mutations in the S4 region isolate the final voltagedependent cooperative step in potassium channel activation. J. Gen. Physiol. 113, 389-414.

Liin, S.I., Silverå Ejneby, M., Barro-Soria, R., Skarsfeldt, M.A., Larsson, J.E., Starck Härlin, F., Parkkari, T., Bentzen, B.H., Schmitt, N., Larsson, H.P., et al. (2015). Polyunsaturated fatty acid analogs act antiarrhythmically on the cardiac IKs channel. Proc. Natl. Acad. Sci. U. S. A. 112, 5714-5719.

Liin, S.I., Larsson, J.E., Barro-Soria, R., Bentzen, B.H., and Larsson, H.P. (2016a). Fatty acid analogue $\mathrm{N}$-arachidonoyl taurine restores function of IKs channels with diverse long QT mutations. ELife 5, e20272.

Liin, S.I., Karlsson, U., Bentzen, B.H., Schmitt, N., and Elinder, F. (2016b). Polyunsaturated fatty acids are potent openers of human M-channels expressed in Xenopus laevis oocytes. Acta Physiol. Oxf. Engl. 218, 28-37. 
Long, S.B., Tao, X., Campbell, E.B., and MacKinnon, R. (2007). Atomic structure of a voltagedependent $\mathrm{K}+$ channel in a lipid membrane-like environment. Nature 450, 376-382.

Lu, Y.-Y., Chen, Y.-C., Kao, Y.-H., Lin, Y.-K., Yeh, Y.-H., Chen, S.-A., and Chen, Y.-J. (2016). Colchicine modulates calcium homeostasis and electrical property of HL-1 cells. J. Cell. Mol. Med. 2O, 1182-1190.

MacKinnon, R. (1991). Determination of the subunit stoichiometry of a voltage-activated potassium channel. Nature 350, 232-235.

MacKinnon, R., Aldrich, R.W., and Lee, A.W. (1993). Functional stoichiometry of Shaker potassium channel inactivation. Science $262,757-759$.

Matteucci, C. (1842). Sur un phenomene physiologique produit par les muscles en contraction. Ann. Chim. Phys. 6, 339-341.

Merritt, H.H., and Putnam, T.J. (1938). Sodium diphenyl hydantoinate in the treatment of convulsive disorders. J. Am. Med. Assoc. 111, 1068-1073.

Moshé, S.L., Perucca, E., Ryvlin, P., and Tomson, T. (2015). Epilepsy: new advances. Lancet Lond. Engl. 385, 884-898.

Neher, E., and Sakmann, B. (1976). Single-channel currents recorded from membrane of denervated frog muscle fibres. Nature 260, 799-802.

Nerbonne, J.M., and Kass, R.S. (2005). Molecular physiology of cardiac repolarization. Physiol. Rev. 85, 1205-1253.

Nernst, W. (1889). Die elektromotorische wirksamkeit der ionen (Engelmann).

Niedergerke, R., and Orkand, R.K. (1966). The dual effect of calcium on the action potential of the frog's heart. J. Physiol. 184, 291-311.

Noble, D. (1962). A modification of the Hodgkin-Huxley equations applicable to Purkinje fibre action and pacemaker potentials. J. Physiol. 16o, 317-352.

Noda, M., Shimizu, S., Tanabe, T., Takai, T., Kayano, T., Ikeda, T., Takahashi, H., Nakayama, H., Kanaoka, Y., and Minamino, N. (1984). Primary structure of Electrophorus electricus sodium channel deduced from cDNA sequence. Nature 312, 121-127.

Ohwada, T., Nonomura, T., Maki, K., Sakamoto, K., Ohya, S., Muraki, K., and Imaizumi, Y. (2003). Dehydroabietic acid derivatives as a novel scaffold for large-Conductance calciumActivated K+ channel openers. Bioorg. Med. Chem. Lett. 13, 3971-3974.

Ottosson, N.E., Liin, S.I., and Elinder, F. (2014). Drug-induced ion channel opening tuned by the voltage sensor charge profile. J. Gen. Physiol. 143, 173-182.

Ottosson, N.E., Wu, X., Nolting, A., Karlsson, U., Lund, P.-E., Ruda, K., Svensson, S., Konradsson, P., and Elinder, F. (2015). Resin-acid derivatives as potent electrostatic openers of voltage-gated K channels and suppressors of neuronal excitability. Sci. Rep. 5, 13278.

Pantazis, A., Savalli, N., Sigg, D., Neely, A., and Olcese, R. (2014). Functional heterogeneity of the four voltage sensors of a human L-type calcium channel. Proc. Natl. Acad. Sci. U. S. A. 111, $18381-18386$. 
Papazian, D.M., Schwarz, T.L., Tempel, B.L., Jan, Y.N., and Jan, L.Y. (1987). Cloning of genomic and complementary DNA from Shaker, a putative potassium channel gene from Drosophila. Science 237, 749-753.

Papazian, D.M., Shao, X.M., Seoh, S.A., Mock, A.F., Huang, Y., and Wainstock, D.H. (1995). Electrostatic interactions of S4 voltage sensor in Shaker K+ channel. Neuron 14, 1293-1301.

Pathak, M., Kurtz, L., Tombola, F., and Isacoff, E. (2005). The cooperative voltage sensor motion that gates a potassium channel. J. Gen. Physiol. 125, 57-69.

Payandeh, J., Scheuer, T., Zheng, N., and Catterall, W.A. (2011). The crystal structure of a voltage-gated sodium channel. Nature 475, 353-358.

Payandeh, J., Gamal El-Din, T.M., Scheuer, T., Zheng, N., and Catterall, W.A. (2012). Crystal structure of a voltage-gated sodium channel in two potentially inactivated states. Nature 486 , 135-139.

Peretz, A., Degani, N., Nachman, R., Uziyel, Y., Gibor, G., Shabat, D., and Attali, B. (2005). Meclofenamic acid and diclofenac, novel templates of KCNQ2/Q3 potassium channel openers, depress cortical neuron activity and exhibit anticonvulsant properties. Mol. Pharmacol. 67, $1053-1066$.

Peretz, A., Sheinin, A., Yue, C., Degani-Katzav, N., Gibor, G., Nachman, R., Gopin, A., Tam, E., Shabat, D., Yaari, Y., et al. (2007). Pre- and Postsynaptic Activation of M-Channels By a Novel Opener Dampens Neuronal Firing and Transmitter Release. J. Neurophysiol. 97, 283-295.

Perozo, E., MacKinnon, R., Bezanilla, F., and Stefani, E. (1993). Gating currents from a nonconducting mutant reveal open-closed conformations in Shaker K+ channels. Neuron 11, $353-358$.

Pongs, O., Kecskemethy, N., Müller, R., Krah-Jentgens, I., Baumann, A., Kiltz, H.H., Canal, I., Llamazares, S., and Ferrus, A. (1988). Shaker encodes a family of putative potassium channel proteins in the nervous system of Drosophila. EMBO J. 7, 1087-1096.

Reuter, H. (1966). Strom-spannungsbeziehungen von purkinje-fasern bei verscheidenen extracellulären calcium-konzentrationen und unter adrenalineinwirkung. Pflügers. Arch. ges. Physiol. 287, 357-367.

Ringer, S. (1882b). Concerning the influence exerted by each of the constituents of the blood on the contraction of the ventricle. J. Physiol. 3, 380-393.

Ringer, S. (1882a). Regarding the action of hydrate of soda, hydrate of ammonia, and hydrate of potash on the ventricle of the frog's heart. J. Physiol. 3, 195-202.6.

Ringer, S. (1883). A further contribution regarding the influence of the different constituents of the blood on the contraction of the heart. J. Physiol. 4, 29-42.

Rolf, S., Haverkamp, W., Borggrefe, M., Musshoff, U., Eckardt, L., Mergenthaler, J., Snyders, D.J., Pongs, O., Speckmann, E.J., Breithardt, G., et al. (2000). Effects of antiarrhythmic drugs on cloned cardiac voltage-gated potassium channels expressed in Xenopus oocytes. Naunyn. Schmiedebergs Arch. Pharmacol. 362, 22-31.

Rudy, B. (1978). Slow inactivation of the sodium conductance in squid giant axons. Pronase resistance. J Physiol 283, 1-21. 
Sakamoto, K., Nonomura, T., Ohya, S., Muraki, K., Ohwada, T., and Imaizumi, Y. (2006). Molecular Mechanisms for Large Conductance Ca2+-Activated K+ Channel Activation by a Novel Opener, 12,14-Dichlorodehydroabietic Acid. J. Pharmacol. Exp. Ther. 316, 144-153.

Sakmann, B., and Neher, E. (1984). Patch clamp techniques for studying ionic channels in excitable membranes. Annu. Rev. Physiol. 46, 455-472.

Sartiani, L., Bochet, P., Cerbai, E., Mugelli, A., and Fischmeister, R. (2002). Functional expression of the hyperpolarization-activated, non-selective cation current If in immortalized HL-1 cardiomyocytes. J. Physiol. 545, 81-92.

Smith-Maxwell, C.J., Ledwell, J.L., and Aldrich, R.W. (1998). Uncharged S4 residues and cooperativity in voltage-dependent potassium channel activation. J. Gen. Physiol. 111, 421439 .

Starkus, J.G., Kuschel, L., Rayner, M.D., and Heinemann, S.H. (1997). Ion Conduction through C-Type Inactivated Shaker Channels. J. Gen. Physiol. 110, 539-550.

Stas, J.I., Bocksteins, E., Jensen, C.S., Schmitt, N., and Snyders, D.J. (2016). The anticonvulsant retigabine suppresses neuronal KV2-mediated currents. Sci. Rep. 6, 35080.

Stevens, M., Peigneur, S., and Tytgat, J. (2011). Neurotoxins and Their Binding Areas on Voltage-Gated Sodium Channels. Front. Pharmacol. 2.

Strege, P., Beyder, A., Bernard, C., Crespo-Diaz, R., Behfar, A., Terzic, A., Ackerman, M., and Farrugia, G. (2012). Ranolazine inhibits shear sensitivity of endogenous $\mathrm{Na}+$ current and spontaneous action potentials in HL-1 cells. Channels 6, 457-462.

Stühmer, W., Conti, F., Suzuki, H., Wang, X.D., Noda, M., Yahagi, N., Kubo, H., and Numa, S. (1989). Structural parts involved in activation and inactivation of the sodium channel. Nature $339,597-603$.

Sun, J., and MacKinnon, R. (2017). Cryo-EM Structure of a KCNQ1/CaM Complex Reveals Insights into Congenital Long QT Syndrome. Cell 169, 1042-1050.e9.

Sun, X., Zhou, D., Zhang, P., Moczydlowski, E.G., and Haddad, G.G. (2007). $\beta$-SubunitDependent Modulation of hSlo BK Current by Arachidonic Acid. J. Neurophysiol. 97, 62-69.

Takahashi, M., Seagar, M.J., Jones, J.F., Reber, B.F., and Catterall, W.A. (1987). Subunit structure of dihydropyridine-sensitive calcium channels from skeletal muscle. Proc. Natl. Acad. Sci. U. S. A. 84, 5478-5482.

Tanabe, T., Takeshima, H., Mikami, A., Flockerzi, V., Takahashi, H., Kangawa, K., Kojima, M., Matsuo, H., Hirose, T., and Numa, S. (1987). Primary structure of the receptor for calcium channel blockers from skeletal muscle. Nature 328, 313-318.

Tashima, T., Toriumi, Y., Mochizuki, Y., Nonomura, T., Nagaoka, S., Furukawa, K., Tsuru, H., Adachi-Akahane, S., and Ohwada, T. (2006). Design, synthesis, and BK channel-opening activity of hexahydrodibenzazepinone derivatives. Bioorg. Med. Chem. 14, 8014-8031.

Tempel, B.L., Papazian, D.M., Schwarz, T.L., Jan, Y.N., and Jan, L.Y. (1987). Sequence of a probable potassium channel component encoded at Shaker locus of Drosophila. Science 237, $770-775$. 
Thompson, C.L., Ng, L., Menon, V., Martinez, S., Lee, C.-K., Glattfelder, K., Sunkin, S.M., Henry, A., Lau, C., Dang, C., et al. (2014). A High-Resolution Spatiotemporal Atlas of Gene Expression of the Developing Mouse Brain. Neuron 83, 309-323.

Tigerholm, J., Börjesson, S.I., Lundberg, L., Elinder, F., and Fransén, E. (2012). Dampening of Hyperexcitability in CA1 Pyramidal Neurons by Polyunsaturated Fatty Acids Acting on Voltage-Gated Ion Channels. PLoS ONE 7, e44388.

Timpe, L.C., Schwarz, T.L., Tempel, B.L., Papazian, D.M., Jan, Y.N., and Jan, L.Y. (1988). Expression of functional potassium channels from Shaker cDNA in Xenopus oocytes. Nature $331,143-145$.

Tompson, D.J., Buraglio, M., Andrews, S.M., and Wheless, J.W. (2016). Adolescent Clinical Development of Ezogabine/Retigabine as Adjunctive Therapy for Partial-Onset Seizures: Pharmacokinetics and Tolerability. J. Pediatr. Pharmacol. Ther. JPPT 21, 404-412.

Tyser, R.C., Miranda, A.M., Chen, C., Davidson, S.M., Srinivas, S., and Riley, P.R. (2016). Calcium handling precedes cardiac differentiation to initiate the first heartbeat. 5, e17113.

Vacher, H., Mohapatra, D.P., and Trimmer, J.S. (2008). Localization and targeting of voltagegated ion channels in mammalian central neurons. Physiol. Rev. 88, 1407-1447.

Vargas, E., Yarov-Yarovoy, V., Khalili-Araghi, F., Catterall, W.A., Klein, M.L., Tarek, M., Lindahl, E., Schulten, K., Perozo, E., Bezanilla, F., et al. (2012). An emerging consensus on voltage-dependent gating from computational modeling and molecular dynamics simulations. J. Gen. Physiol. 140, 587-594.

Vassilev, P., Scheuer, T., and Catterall, W.A. (1989). Inhibition of inactivation of single sodium channels by a site-directed antibody. Proc. Natl. Acad. Sci. U. S. A. 86, 8147-8151.

Vassilev, P.M., Scheuer, T., and Catterall, W.A. (1988). Identification of an intracellular peptide segment involved in sodium channel inactivation. Science $241,1658-1661$.

Villalba-Galea, C.A. (2016). Hysteresis in voltage-gated channels. Channels 11, 140-155.

Wang, H.-S., Pan, Z., Shi, W., Brown, B.S., Wymore, R.S., Cohen, I.S., Dixon, J.E., and McKinnon, D. (1998). KCNQ2 and KCNQ3 Potassium Channel Subunits: Molecular Correlates of the M-Channel. Science 282, 1890-1893.

West, J.W., Patton, D.E., Scheuer, T., Wang, Y., Goldin, A.L., and Catterall, W.A. (1992). A cluster of hydrophobic amino acid residues required for fast $\mathrm{Na}(+)$-channel inactivation. Proc. Natl. Acad. Sci. U. S. A. 89, 10910-10914.

Woodbury, L.A., Woodbury, J.W., and Hecht, H.H. (1950). Membrane resting and action potentials of single cardiac muscle fibers. Circulation 1, 264-266.

Woodbury, L.A., Hecht, H.H., and Christopherson, A.R. (1951). Membrane resting and action potentials of single cardiac muscle fibers of the frog ventricle. Am. J. Physiol. 164, 307-318.

Wu, C., V Gopal, K., Lukas, T.J., Gross, G.W., and Moore, E.J. (2014). Pharmacodynamics of potassium channel openers in cultured neuronal networks. Eur. J. Pharmacol. 732, 68-75.

Wu, J., Yan, Z., Li, Z., Qian, X., Lu, S., Dong, M., Zhou, Q., and Yan, N. (2016). Structure of the voltage-gated calcium channel $\mathrm{Ca}_{\mathrm{v}} 1.1$ at $3.6 \AA$ resolution. Nature $537,191-196$. 
Wu, X., Silverå Ejneby, M., Ottosson, E.N., Elinder, F., and Konradsson, P. (2018). A SuzukiMiyaura Coupling of ortho-Hydroxyaryl Bromide with Isopropenylboronic Pinacol Ester: Synthesis of the Potassium-Channel Opener (+)-Callitrisic Acid. Eur. J. Org. Chem. 2018, 1730-1734.

Wulff, H., Castle, N.A., and Pardo, L.A. (2009). Voltage-gated Potassium Channels as Therapeutic Drug Targets. Nat. Rev. Drug Discov. 8, 982-1001.

Wuttke, T.V., Seebohm, G., Bail, S., Maljevic, S., and Lerche, H. (2005). The new anticonvulsant retigabine favors voltage-dependent opening of the Kv7.2 (KCNQ2) channel by binding to its activation gate. Mol. Pharmacol. 67, 1009-1017.

Xiong, Q., Sun, H., Zhang, Y., Nan, F., and Li, M. (2008). Combinatorial augmentation of voltage-gated KCNQ potassium channels by chemical openers. Proc. Natl. Acad. Sci. 105, 3128-3133.

$\mathrm{Xu}$, X., Erichsen, D., Börjesson, S.I., Dahlin, M., Amark, P., and Elinder, F. (2008). Polyunsaturated fatty acids and cerebrospinal fluid from children on the ketogenic diet open a voltage-gated K channel: a putative mechanism of antiseizure action. Epilepsy Res. 80, 5766.

Yang, Y., Yan, Y., and Sigworth, F.J. (1997). How does the W434F mutation block current in Shaker potassium channels? J. Gen. Physiol. 109, 779-789.

Yang, Z., Shen, W., Rottman, J.N., Wikswo, J.P., and Murray, K.T. (2005). Rapid stimulation causes electrical remodeling in cultured atrial myocytes. J. Mol. Cell. Cardiol. 38, 299-308.

Yazdi, S., Stein, M., Elinder, F., Andersson, M., and Lindahl, E. (2016). The Molecular Basis of Polyunsaturated Fatty Acid Interactions with the Shaker Voltage-Gated Potassium Channel. PLoS Comput. Biol. 12, e1004704.

Young, J.. (1936). The structure of nerve fibres in cephalopods and crustacea. Proc. R. Soc. Lond. B. 121, 319-337.

Young, J.Z. (1938). The functioning of the giant nerve fibres of the squid. J. Exp. Biol. 15, 170185.

Yu, F.H., and Catterall, W.A. (2004). The VGL-chanome: a protein superfamily specialized for electrical signaling and ionic homeostasis. Sci. STKE Signal Transduct. Knowl. Environ. 2004, re15.

Yu, H., Lin, Z., Mattmann, M.E., Zou, B., Terrenoire, C., Zhang, H., Wu, M., McManus, O.B., Kass, R.S., Lindsley, C.W., et al. (2013). Dynamic subunit stoichiometry confers a progressive continuum of pharmacological sensitivity by KCNQ potassium channels. Proc. Natl. Acad. Sci. U. S. A. $110,8732-8737$.

Zamponi, G.W., Striessnig, J., Koschak, A., and Dolphin, A.C. (2015). The Physiology, Pathology, and Pharmacology of Voltage-Gated Calcium Channels and Their Future Therapeutic Potential. Pharmacol. Rev. 67, 821-870. 


\section{Articles}

The articles associated with this thesis have been removed for copyright reasons. For more details about these see:

http://urn.kb.se/resolve?urn=urn:nbn:se:liu:diva-147838 